\title{
The carnivoran community from the Miocene of Sandelzhausen (Germany)
}

\author{
Doris Nagel $\cdot$ Clara Stefen $\cdot$ Michael Morlo
}

Received: 23 May 2007/ Accepted: 10 January 2008/Published online: 13 February 2009

(C) Springer-Verlag 2009

\begin{abstract}
From the Bavarian Early/Middle Miocene (MN5) site Sandelzhausen, nine species of carnivoran mammals are identified including the hemicyonine ursid Hemicyon stehlini, the amphicyonids Amphicyon cf. major and Pseudarctos bavaricus, the mustelids Ischyrictis zibethoides and Martes cf. munki, the mephitid Proputorius pusillus, the viverrid Leptoplesictis cf. aurelianensis, the felid Pseudaelurus romieviensis, and finally the recently described barbourofelid Prosansanosmilus eggeri. With these taxa present, Sandelzhausen shows a carnivoran community typical, though deprived, for the Lower to Middle Miocene of Europe, but different from roughly contemporary Mediterranean faunas such as those from Çandir or Paşalar in Turkey.
\end{abstract}

Keywords Europe - Germany · Early/Middle Miocene · Carnivora $\cdot$ Systematics $\cdot$ Palaeobiogeography

Kurzfassung In der bayerischen unter-/mittelmiozänen (MN5) Fundstelle Sandelzhausen konnten 9 Raubtierarten identifiziert werden. Dazu gehören der bärenartige

\section{Nagel $(\bowtie)$}

Department of Palaeontology, Universität Wien,

Althanstrasse 14, 1090 Wien, Germany

e-mail: doris.nagel@univie.ac.at

\section{Stefen}

Staatliche Naturhistorische Sammlungen Dresden,

Museum für Tierkunde, Königsbrücker Landstraße 159,

01109 Dresden, Germany

e-mail: clara.stefen@snsd.smwk.sachsen.de

\section{Morlo}

Forschungsinstitut Senckenberg, Abt. Messelforschung,

Senckenberganlage 25, 60325 Frankfurt, Germany

e-mail: Michael.Morlo@senckenberg.de
Hemicyonide Hemicyon stehlini, die Amphicyoniden Amphicyon cf. major und Pseudarctos bavaricus, die Musteliden Ischyrictis zibethoides und Martes cf. munki, der Mephitine Proputorius pusillus, die viverride Form Leptoplesictis cf. aurelianensis, der felide Pseudaelurus romieviensis und der kürzlich beschriebene Barbourofelide Prosansanosmilus eggeri. Die carnivore Vergesellschaftung in Sandelzhausen ist damit typisch, wenn auch ein wenig verarmt, für das untere bis mittlere Miozän in Europa, aber doch verschieden von den ungefähr gleich alten mediterranen Faunen wie zum Beispiel Çandir und Paşalar in der Türkei.

Schlüsselwörter Europa $\cdot$ Deutschland . Unter-/Mittelmiozän · Carnivora · Systematik ·

Paläobiogeographie

$\begin{array}{ll}\text { Abbreviations } \\ \text { BSPG } & \begin{array}{l}\text { Bayerische Staatssammlung für Paläontologie } \\ \text { und Geologie, München }\end{array} \\ \text { MNHNP } & \begin{array}{l}\text { Muséum National d'Histoire Naturelle, Paris } \\ \text { NOW }\end{array} \\ & \begin{array}{l}\text { Neogene of the Old World. Database of fossil } \\ \text { mammals (http://www.helsinki.fi/science/now) }\end{array}\end{array}$

\section{Introduction}

The fossil locality Sandelzhausen in the Northalpine Molasse Basin is known since 1959 and was excavated in several campaigns by the University of Munich together with the Bayerische Staatssammlung für Paläontologie und Geologie (Fahlbusch 1974a, b; Fahlbusch and Gall 1970; Fahlbusch et al. 1972, 1974; Fahlbusch and Liebreich 1999; Fahlbusch 2003). The locality yielded abundant 
material of a diverse vertebrate fauna with more than 50,000 objects. Sandelzhausen is late Early or early Middle Miocene in age and belongs to the middle part of Neogene Mammal Biozone MN5 (Daxner-Höck 2003).

More details on the geology and stratigraphy of the locality are given in Moser et al. (2009). Some carnivoran specimens were already published, but partly were wrongly identified. This is indicated in the different sections.

\section{Materials and methods}

The carnivores described herein all come from layers B and $\mathrm{C}$ of the section (see Moser et al. 2009 this volume for more stratigraphic/geological details), between 25 and $100 \mathrm{~cm}$ above the base of the section. All material is housed in the Bayerische Staatssammlung für Paläontologie und Geologie, Munich, Germany (BSPG). The collection numbers of all specimens start with "BSPG 1959 II," which is omitted in the following text. Lower teeth are referred to by lower letters, as in " $m 1$ ", uppers by capitals, as in "P4", lower canines as "c inf." and upper canines as "C sup.". Measurements were taken with callipers to the closest $0.1 \mathrm{~mm}$. Description of tooth morphology of Amphicyon follows Peigné and Heizmann (2003); all others follow Thenius (1989).

The following description focuses on the dental material. Postcranial material is evaluated if the taxonomic assignment was clear. The remaining postcranial material needs further investigation.

\section{Systematic palaeontology}

Order Carnivora Bowdich, 1821.

Family Amphicyonidae Trouessart, 1885.

Subfamily Amphicyoninae Trouessart, 1885.
Genus Amphicyon Lartet, 1836.

Type species: Amphicyon major Blainville, 1841.

Amphicyonidae is a carnivorous family that originated in the Late Eocene and vanished in the Late Miocene. It consists of a diverse group of species with different food preferences from omnivory to hypercarnivory (Viranta 1996). Within the subfamily Amphicyoninae a regular and steady increase in size is noticeable (Ginsburg 1999). Although Lartet mentioned the name "Amphicyon" for the first time in 1836, it took a while until a diagnosis was added (for complete history see Kuss 1965). The genus Amphicyon is characterized by spacings between their premolars, a single rooted $\mathrm{p} 2, \mathrm{p} 4$ with posterior cusp, a retention of the entoconid on $\mathrm{m} 1$, protocone on $\mathrm{P} 4$ can be reduced, and an enlarged M2 (Ginsburg 1961; Kuss 1965; Viranta 1996). It was widespread throughout Europe in the Early and Middle Miocene (see NOW) but is also cited from the early Middle Miocene of Africa (Morales et al. 1998).

Amphicyon cf. major Blainville, 1841.

Synonymy list: for complete list see Kuss (1965) and Viranta (1996).

*1841 Amphicyon major Blainville: pl. 14.

Material: 8106: right maxillar fragment with alveoli of M1-M2; 8241: upper incisor; 8100: left C sup.; 2222: right C sup.; 2198: right $C$ sup.; 8101: left $C$ sup., strongly worn; 9012: left $\mathrm{C}$ sup., strongly worn and crown broken; 2202: right $\mathrm{P} 4$ with fourth root below metacone blade (Figs. 1a, 11f-h); 2224: left P4; 2225: right P4, strongly worn; 8099: left M1 (Fig. 1c); 2213: right M1, buccal-posterior root missing, worn (Fig. 11i); 8097: right M1, strongly worn; 8102: right M1, buccal part broken; 16202: left M1; 2226: right M1 (Fig. 1b); 8103: right M1 fragment; 88: right M2; 8220: right M2, buccal root broken; 8098: right M2 (Fig. 11J); 8222: right M3. 8095: right lower jaw fragment with $\mathrm{m} 1$ and $\mathrm{m} 2$ in place, p4 attached (Fig. 11d); 8096: right lower jaw fragment with alveoli for p2-m3, c inf.
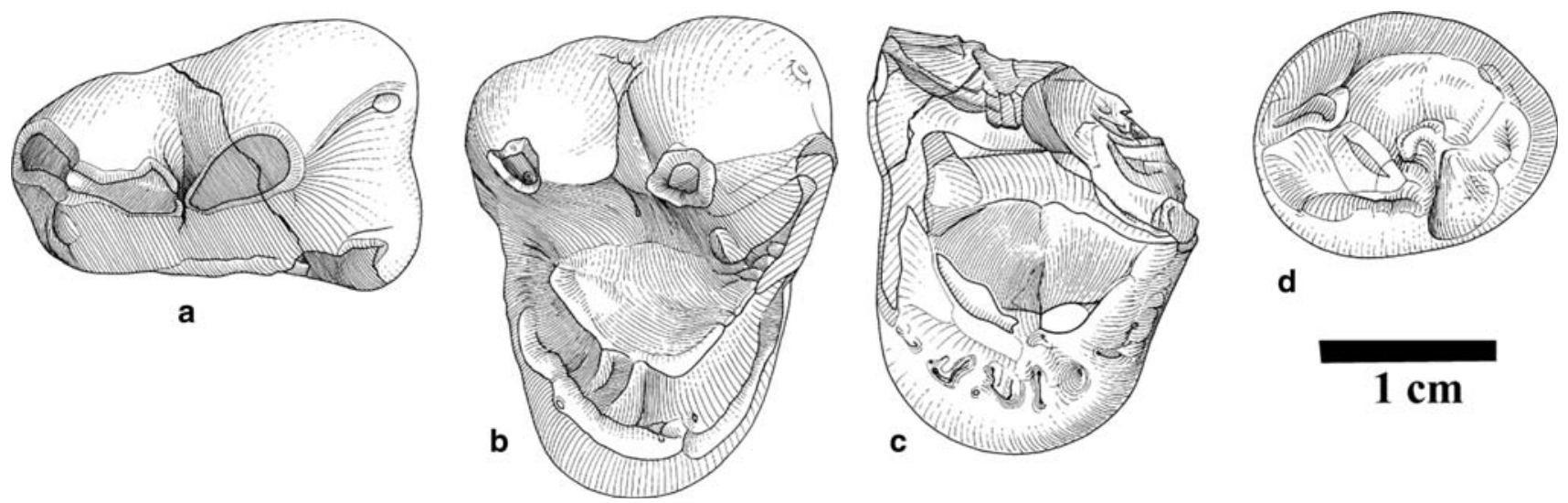

Fig. 1 Amphicyon cf. major Blainville, 1841. a 2202, right P4; b 2226, right M1; c 8099, left M1; d 2235, left m3; all occlusal views 
alveolus is broken; 2200: left lower jaw fragment with $\mathrm{m} 1$ and $\mathrm{m} 2$ in place (Fig. 11a-c); 2199: right $\mathrm{c}$ inf.; 2231: right c inf., crown broken; 8223: left p4; 2227: right $\mathrm{m} 1$ with metaconid and talonid; 2236 : right $\mathrm{m} 1$, only metaconid and talonid preserved; 8224: right $\mathrm{m} 1$ fragment; 2214: left $\mathrm{m} 2$; 2233: right $\mathrm{m} 2$; 8082: left $\mathrm{m} 3$ (Fig. 11E); 2235: right $\mathrm{m} 3$; 2229: left $\mathrm{m} 3$; 2244: right $\mathrm{m} 3$; 3938: left $\mathrm{m} 3$ fragment; 3717: right femur; 2201: left femur (Fig. 2t-u); 8247: right radius (Fig. 2r, s); 2204: right calcaneus (Fig. 2p, q); 2223 : left calcaneus; 8249: right calcaneus; 2203: left astragalus (Fig. 2n, o); 8107: left astragalus (Fig. 21, m); 8256: right Mc1; 2242: left Mc2; 8258: right Mc4; 2240: left Mc5; 2241: right Mc5; 8159: right Mt1 (Fig. 2d, h); 8169: right Mt2 (Fig. 2c, g, k); 2228: left Mt2; 2243: right Mt3 (Fig. 2b, f, j); 8173: right Mt4 (Fig. 2a, e, i); 8340: right Mt4 fragment; 16218: right Mt4 fragment; 2215: right Mt5; 8257: left tarsale 3; 2205, 2238, 8104, 8152, 8157, 8177, $2239,8264,8265,8266$ and 8342: phalange $1 ; 8163,8164$, 2218, 2245, 2248, 2249, 8349 and 8370: phalange 2; 2220 and 2232: last digit.

Description: From the upper jaw, only single teeth are present. The protocone of P4 is very weakly developed. Especially in 2225 and on 2202 (Fig. 1a) a swelling on the buccal-exterior part indicates a parastyle. The metastyle blade is approximately of the same length as the paracone. 2202 carries a fourth root close to the one under the metastyle root (Fig. 11f, g). The paracone of M1 is more strongly developed than the metacone and the conule show different variations. In 2213 (Fig. 11i), paraconule and metaconule are very small. In 2226 the metaconule is crestlike and the paraconule is closely attached to the paracone (Fig. 1b). The lingual border can be triangular in shape without differentiation (2213) or can be surrounded by numerous enamel folds, which lead to the protocone and give the tooth a more rounded shape (8099, Fig. 1c). In $\mathrm{M} 1$, the cingulum on the anterior rim of the paracone does not form a knob at the basal part of the tooth, but extends upwards along the paracone and merges with the anteroposterior crest along the paracone and metacone (2226). 8099 shows an elongated protocone and directly adjacent a nearly equally well-developed metaconule similar to A. major from Sansan.

The length-to-width ratio of the M2 (8098) is only slightly wider than the M1. The paracone is larger than the metacone, the protocone is rather weakly developed, and the lingual part is again marked with small enamel folds (Fig. 11j). The M3 is double-rooted (8222) and the anterior-buccal part, the position of the paracone, is a bit larger. In general, the tooth is surrounded by a thick rim with a depression in the middle.

The lower jaw (2200, Fig. 11a-c) still retains an alveolus for a single rooted p1. Unfortunately, the second lower jaw 8095 (Fig. 11d) is damaged at the front and gives no information about the presence of a p1. Both mandibles show alveoli for $\mathrm{p} 2$ and $\mathrm{p} 3$, with at most a very small diasteme between the premolars. The p4 (2200) has no anterior cusp and a posterior cusp is close to the main cusp. The whole tooth is asymmetrical and broader at its posterior end. The $\mathrm{m} 1$ consists of a paraconid lower than the protoconid and a metaconid which is very close to the protoconid, but does not lean further back than the main cusp; therefore, it is not visible in buccal view. The talonid carries a prominent hypoconid, which is separated from the entoconid by a narrow groove. Paraconid, protoconid, and hypoconid are more or less in line for trenching. In 8095, the enamel of $\mathrm{m} 1$ is slightly rugose. The double-rooted $\mathrm{m} 2$ has no paraconid; the protoconid and the metaconid are equal in size with the protoconid being placed further forward than the metaconid. The talonid of the $\mathrm{m} 2$ is about the same size as the front part of the tooth with a hypoconid on its buccal side and no entoconid in the lingual part. The single-rooted $\mathrm{m} 3$ carries a protoconid with a crest leading from the anterior part of the tooth to the posterior end with no indication of a hypoconid. The talonid is basined and may carry two very small cusplets in the middle (8082) or a very small s-like crest (2235). The whole tooth is surrounded by the crest, which extends anteriorly and posteriorly from the protoconid, by a crest coming from the antero-lingual part, extending over the small metaconid and closing the circle through a cingulid on the posterolingual part of the tooth.

Comparison and distribution: This amphicyonid of Sandelzhausen differs from other contemporary amphicyonid genera of Europe as follows:

Pseudocyon sansaniensis Filhol, 1881 (pl. 10 Figs. 1, 3, 4) has an $\mathrm{m} 1$ with the metaconid, which is isolated and placed in a more posterior position. Its $\mathrm{m} 2$ is developed in a more sectorial way, with a strong protoconid, a reduced, very lingually placed metaconid, and a trenchant talonid with the hypoconid almost centrally situated.

Ictiocyon was erected on the basis of a single species, Ictiocyon socialis, by Ginsburg (1992). It differs from Amphicyon and Pseudocyon in having the talonids of $\mathrm{m} 1$ and $\mathrm{m} 2$ larger than the respective trigonids, and paracone and metacone higher in M1.

Pseudarctos was defined by Schlosser (1899). The genus is characterized by the absence of $\mathrm{p} 1$, an asymmetrical talonid in which the entoconid is as well developed as the hypoconid, and an enlargement in the $\mathrm{m} 2$.

Euroamphicyon was erected by Viranta (1996) as genus, but listed as a subgenus by Ginsburg (1999). According to Viranta (1996) the taxon is characterized by a M2, which is shorter than in Amphicyon. Moreover, $\mathrm{m} 1$ and $\mathrm{m} 2$ are reduced in the inner part (Viranta 1996).

We thus assign the Sandelzhausen amphicyonid to Amphicyon. 


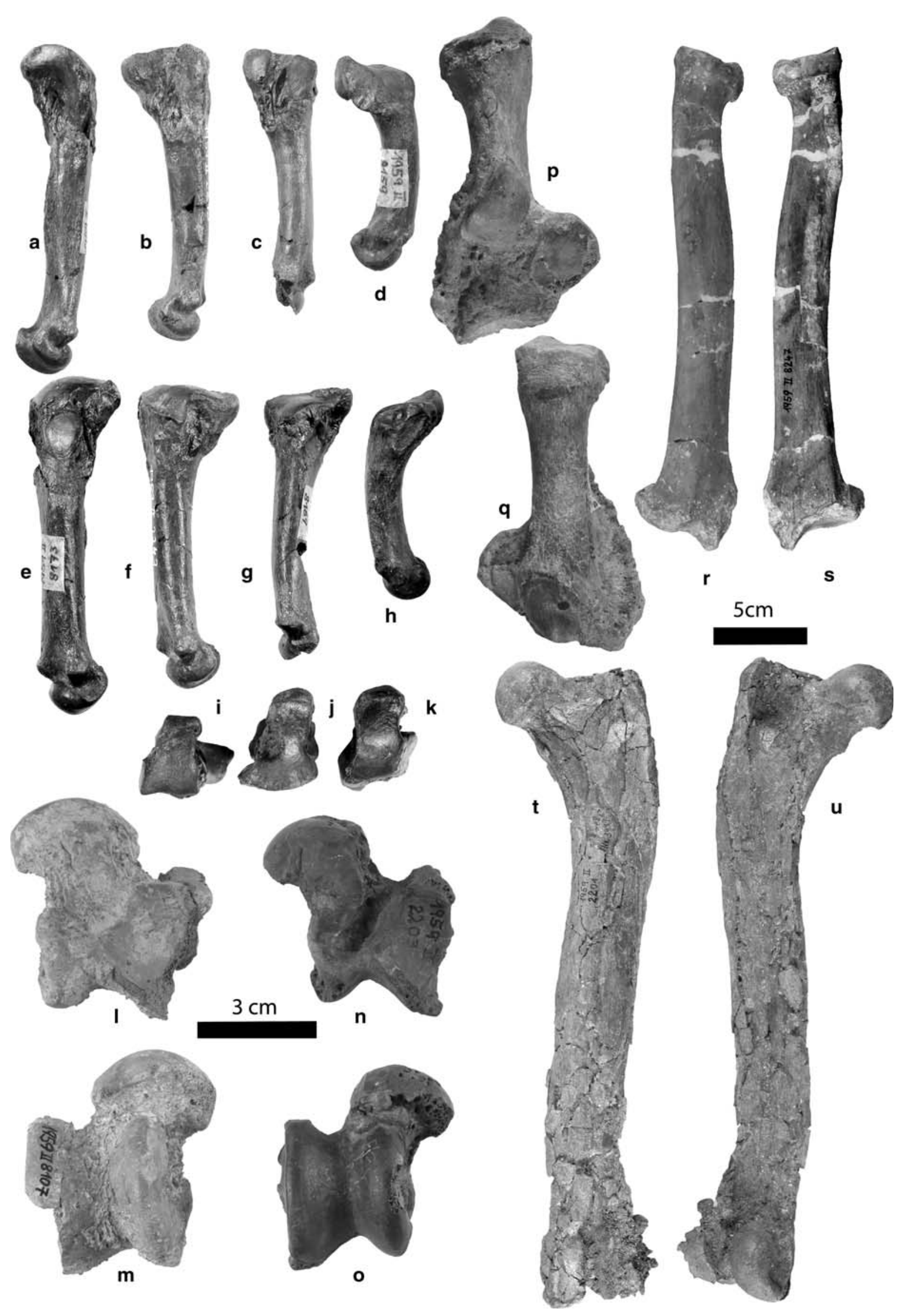


4 Fig. 2 Amphicyon cf. major Blainville, 1841. a, e, i 8173, right Mt4; b, f, j 2243, right Mt3; c, g, k 8169, right Mt2; d, h 8159, right Mt1 (a-d medial; e-h lateral); l-m 8107, left astragalus; I proximal view, m distal view; n, o 2203, left astragalus; n proximal view; o distal view; p, q 2204, right calcaneus; p proximal view; q distal view; r, s 8247 , right radius; $\mathbf{r}$ anterior view; $\mathbf{s}$ posterior view; $\mathbf{t}, \mathbf{u} 2201$, left femur; $\mathbf{t}$ anterior view; $\mathbf{u}$ posterior view

Concerning size, the measurements of the Sandelzhausen material place it between Amphicyon major and A. steinheimensis (Fraas 1885) (Fig. 3), but still in the lower size range of A. major from Sansan (France, MN6). The Amphicyon from Sandelzhausen differs morphologically from A. steinheimensis and other contemporary Amphicyon species of Europe by the following characters: in $\mathrm{P} 4$ from Sandelzhausen the protocone is not as strongly isolated as in A. steinheimensis or A. bohemicus (Schlosser 1899) (Figs. 1a, 11h, 2202); in M1, the paracone is larger than the metacone, the metaconule is more strongly developed than the paraconule, and the buccal border is slightly convex instead of being concave (Fig. 1b, 2226 and Fig. 11i, 2213); the M3 is double-rooted (8222) and not single-rooted as in A. steinheimensis and also most specimens of A. major. However, the M3 is as reduced as in A. bohemicus and A. steinheimensis. The $\mathrm{p} 2$ and $\mathrm{p} 3$ are double-rooted and not single-rooted as in A. steinheimensis, the $\mathrm{m} 1$ is low crowned, the metaconid is less posterior placed, and the entoconid is smaller.

The lower dentition differs from A. gutmanni Kittl, 1891 in having the $\mathrm{m} 1$ metaconid not placed more posterior than the protoconid. The hypoconid of A. gutmanni is larger and in addition an entoconid is present in that species which is missing in the Sandelzhausen Amphicyon. Furthermore, in A. gutmanni the lingual margin of the talonid is serrated. A. bohemicus is clearly smaller than Amphicyon from
Sandelzhausen. A. giganteus Schinz, 1825 is defined as different from A. major only by its larger size (Ginsburg 1999; Viranta 1996) and thus the material of Sandelzhausen cannot be referred to this species as it is smaller than A. major.

A. major is the best-known Amphicyon species in Europe and has a rather large variation in size as well as in morphology. A. major Blainville, 1841 ranges in Western Europe from MN4 to MN8 (Ginsburg 1999). The Sandelzhausen material may serve as an example of how the ancestral morphology of A. major from Sansan and maybe even A. steinheimensis may have looked like. Plesiomorphic characters are (1) the retention of a small and single rooted p1, (2) a double-rooted p2, (3) the lack of diastemes between the premolar alveoli, (4) the small $\mathrm{m} 1$ metaconid is not posterior to the protoconid, (5) the lack of a entoconid on the $\mathrm{m} 1$ talonid, (6) the poorly differentiated $\mathrm{P} 4$ protocone, maybe because the paraconid on $\mathrm{m} 1$ is not as developed as in A. major or A. steinheimensis, and (7) a double-rooted M3, a character not described in A. major so far. In these characters the material supports the proposed (Ginsburg 1999) origin of Amphicyon from Cynelos (Jourdan 1848). It is of course too large to belong to any known Cynelos, but the presence of these plesiomorphic characters sheds some doubt on the proposed direct descent of A. major from A. giganteus (Tables 1,2).

Genus Pseudarctos Schlosser, 1899.

Type species: Pseudarctos bavaricus Schlosser, 1899.

Pseudarctos is a small amphicyonid, lacking p1 and with a very bunodont dentition. The p2-p4 show no accessory cusps. There is a tendency to enlarge the asymmetric talonid in $\mathrm{m} 1$ and $\mathrm{m} 2$ and to enforce the entoconid while the hypoconid remains low.
Fig. 3 Scatter diagram of $\mathrm{p} 4$, $\mathrm{m} 1, \mathrm{~m} 2$, and $\mathrm{m} 3$ of Amphicyon cf. major from Sandelzhausen in comparison with $A$. steinheimensis from Steinheim and A. major from Sansan. Comparative measurements taken from Heizmann (1973) and Roth (1989). Each point represents an individual specimen

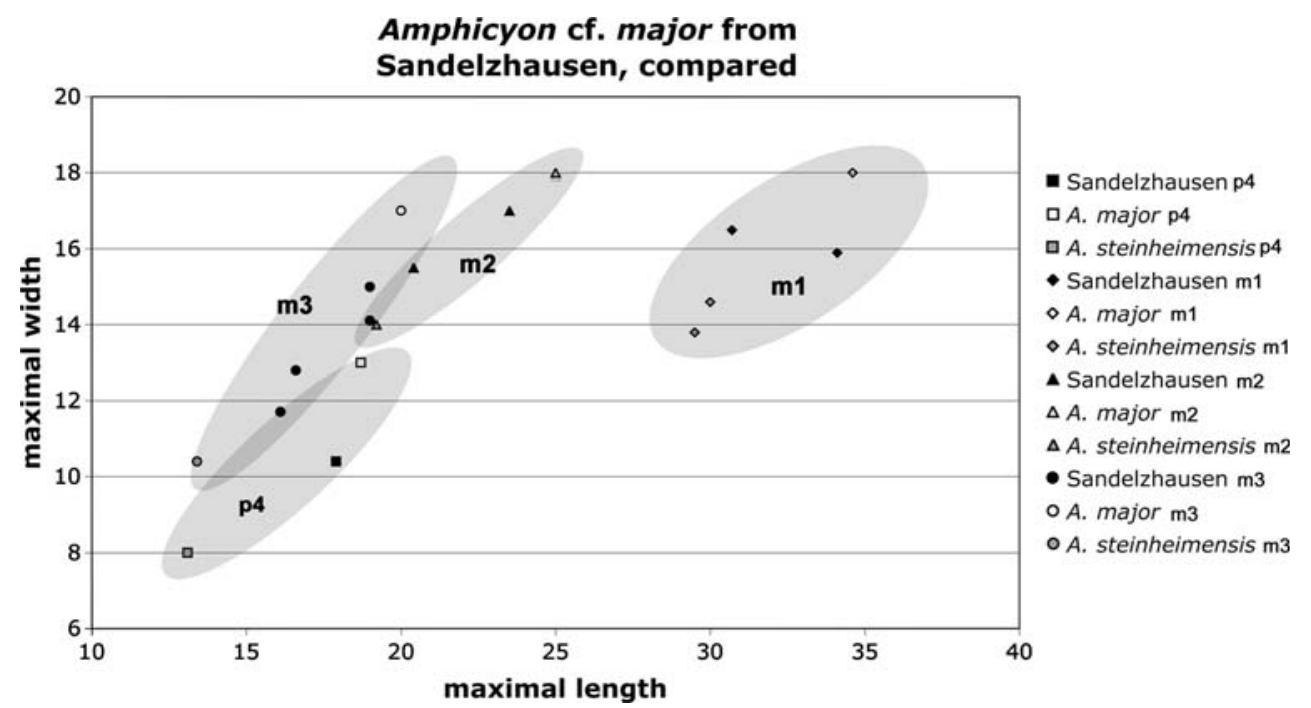



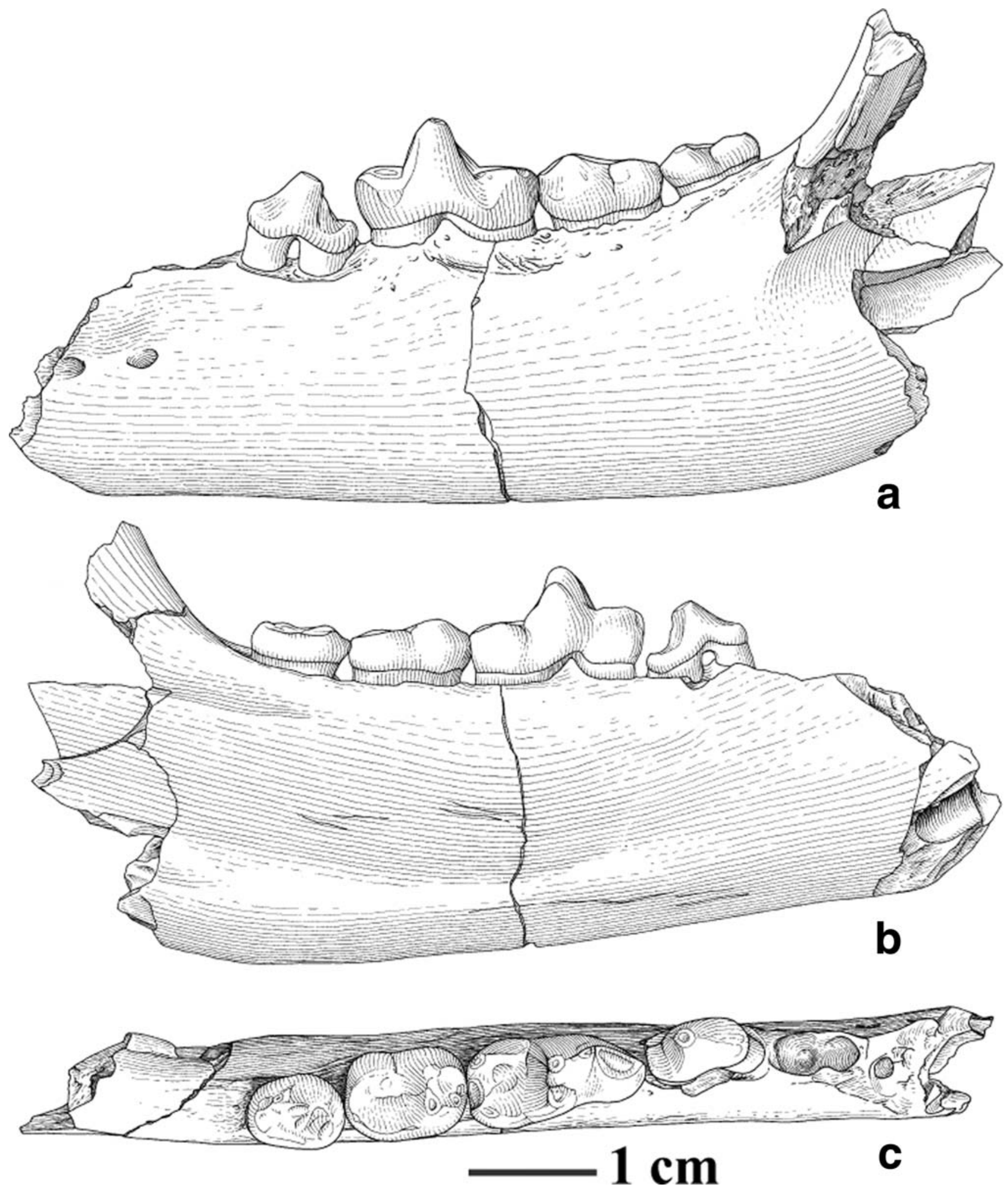

Fig. 4 Pseudarctos bavaricus (Schlosser, 1899) (8061: left mandible with alveoli of c inf., p3, p4-m3) from Sandelzhausen. a buccal view; b lingual view; c occlusal view

The genus Pseudarctos is thought to decrease in size from MN3 to MN9. Ginsburg (1992) split the genus into two species and lineages: the older and larger one,
Ictiocyon socialis (retaining four lower premolars) from MN3 to MN4 and the younger and smaller P. bavaricus (with three lower premolars only) from MN4b to MN9. 
Table 1 Teeth measurements (mm) from Amphicyon major Blainville, 1841
Specimens in brackets represent broken

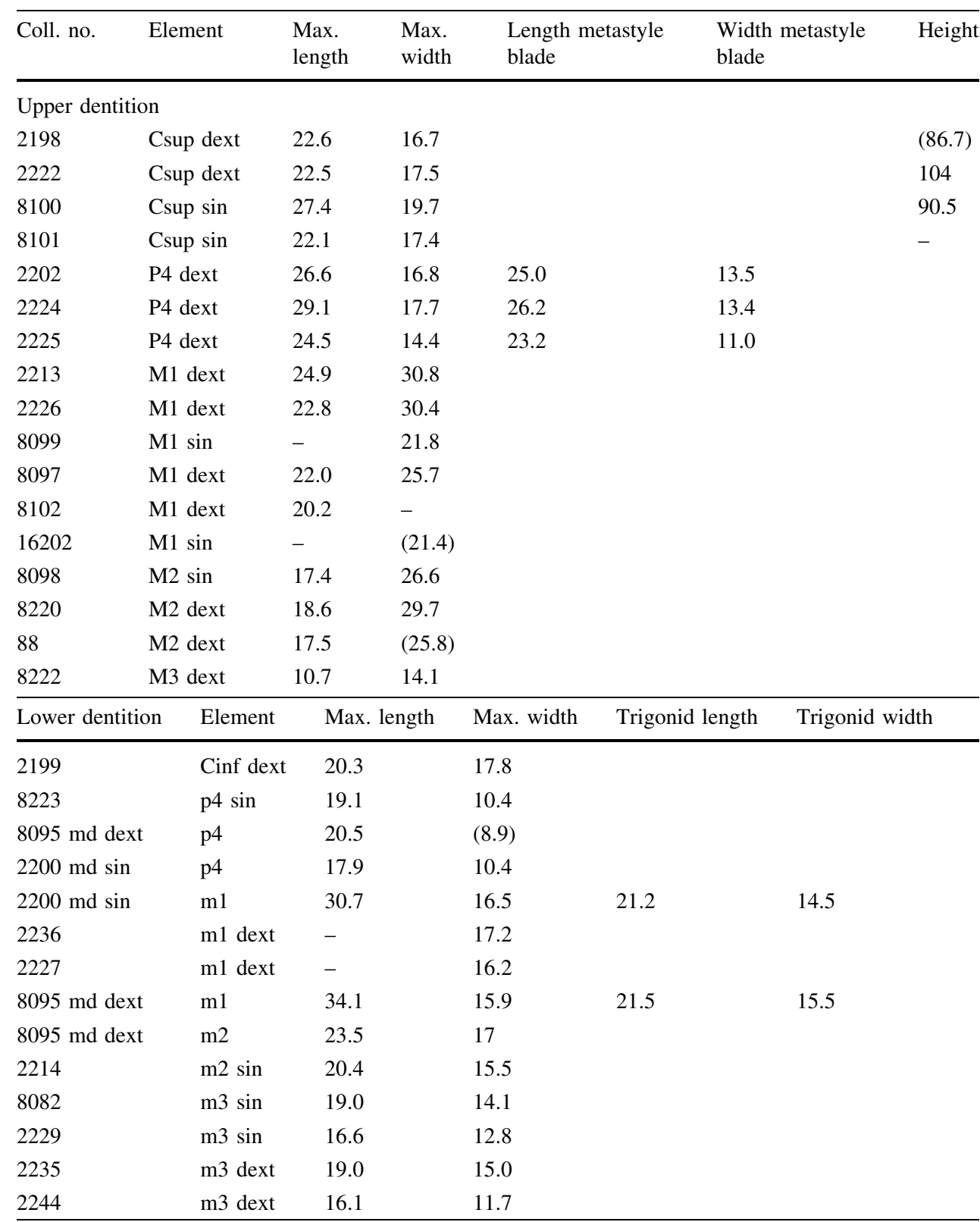

left m3, damaged; 8238: left M1, buccal-posterior part broken (Fig. 11z).

Pseudarctos bavaricus is the only member of the genus Pseudarctos sensu stricto, but was divided by Ginsburg (1992) into three stratigraphically based, subsequent subspecies: $P . b$. beaucensis (MN4b), P. b. pontignensis (MN5), and $P$. b. bavaricus (MN6-MN8). The differences mainly concern size and variations of the talonid of $\mathrm{m} 1$ and the entoconid of m1. Material from, e.g., Häder (Germany, MN5) and Sansan (France, MN6) was assigned to the third subspecies. This subspecies division is followed here only for reasons of discussion.

Description: Only the alveoli of a single-rooted p2 (8060) and a double-rooted p3 $(8060,8061)$ are present among the material from Sandelzhausen. In 8060 and 8061, (Fig. $11 \mathrm{w}-\mathrm{y}$ ); 5295: right $\mathrm{m} 3$ with missing roots; 16203: 
Table 2 Postcranial measurements ( $\mathrm{mm}$ ) of the teeth from Amphicyon major Blainville, 1841

\begin{tabular}{|c|c|c|c|c|c|c|c|c|c|}
\hline Coll. no. & Element & $\begin{array}{l}\text { Total } \\
\text { length }\end{array}$ & $\begin{array}{l}\text { Length } \\
\text { proximal } \\
\text { ant/post }\end{array}$ & $\begin{array}{l}\text { Width } \\
\text { proximal } \\
\text { lat/med }\end{array}$ & $\begin{array}{l}\text { Length } \\
\text { distal } \\
\text { ant/post }\end{array}$ & $\begin{array}{l}\text { Width distal } \\
\text { lat/med }\end{array}$ & $\begin{array}{l}\text { Diaphysis } \\
\text { lateral }\end{array}$ & $\begin{array}{l}\text { Diaphysis } \\
\text { medial }\end{array}$ & $\begin{array}{l}\text { Total } \\
\text { width }\end{array}$ \\
\hline 3717 & Femur dext & 310.0 & (91) & & 70.6 & & 37.4 & $(24.4)$ & \\
\hline 2201 & Femur sin & 325.0 & 78.8 & & - & & 40.3 & - & \\
\hline 8247 & Radius dext & 259.0 & 40.0 & 33.4 & 51.3 & 30.6 & 29.4 & 17.3 & 38.8 \\
\hline 2204 & Calcaneus dext & 78.0 & & & & & & & 40.4 \\
\hline 2222 & Calcaneus sin & 77.8 & & & & & & & 45.0 \\
\hline 8249 & Calcaneus & - & & & & & & & 45.2 \\
\hline 8107 & Astragalus sin & 50.0 & & & & & & & 43.9 \\
\hline 2203 & Astragalus sin & 45.0 & & & & & 9.4 & & \\
\hline 8256 & Mc1 dext & 42.4 & 15.8 & 15.6 & 11.8 & 13.5 & 10.9 & & \\
\hline 2242 & $\mathrm{Mc} 2 \sin$ & 64.2 & 19.6 & 14.1 & 17.7 & 17.5 & - & & \\
\hline 8258 & Mc4 dext & - & 22.8 & 19.8 & - & - & - & & \\
\hline 2240 & Mc5 sin & 61.2 & 15.5 & 18.6 & - & - & 8.9 & & \\
\hline 2241 & Mc5 dext & 61.8 & 16.1 & 18.0 & 15.2 & 14.5 & 11.2 & 9.2 & \\
\hline 8159 & Mt1 dext & 45.4 & 13.6 & 18.5 & 11.0 & 13.0 & 10.2 & & \\
\hline 8169 & Mt2 dext & $(63.5)$ & 18.9 & 13 & - & 16.0 & 9.8 & & \\
\hline 2243 & Mt3 dext & 79.5 & 21.3 & 16.6 & 13.3 & 16.5 & 10.4 & & \\
\hline 8173 & Mt4 dext & 78.0 & 20.2 & 11.9 & 13.7 & 17.2 & - & & \\
\hline 8340 & Mt4 dext & - & 18.6 & 12.6 & - & - & 10.6 & & \\
\hline 2215 & Mt5 dext & 71.4 & 15.4 & 22.4 & 13.1 & 15.4 & & & 18.0 \\
\hline 8257 & Tarsale 3 sin & 30.9 & & & & & & & \\
\hline
\end{tabular}

Specimens in brackets represent broken

p4 have no anterior accessory cusps but 8061 carries the remnant of a posterior accessory cusp (Fig. 4). Both $\mathrm{p} 4$ have a strong posterior base. The trigonid of $\mathrm{m} 1(8060,8061$, and 8081) reveals a metaconid, which is higher than the paraconid and placed slightly posteriorly to the protoconid. The talonid of $\mathrm{m} 1$ is broader than the trigonid, with a hypoconid not larger than a swelling. The entoconid can be identified as a small enhancement of the lingual talonid border (8081). The lingual side of the talonid displays no rugose enamel or cuspids. As in $\mathrm{m} 1$, the $\mathrm{m} 2$ has a larger talonid with no distinct cusps. On the trigonid, protoconid and metaconid are of equal size and the paraconid is only a small cusplet on the anterior border of the tooth. In $\mathrm{m} 3$, the small protoconid forms a crest on the lingual as well as on the buccal side. The talonid of the $\mathrm{m} 3$ narrows into the posterior lingual part. The M1 is slightly asymmetrical with the anterior side being broader than the posterior one. The paracone is well developed, but the part carrying the metacone is broken and can therefore not be compared. No real protocone is developed in M1, only a crest starting on the anterior side of the paracone and extending to the posterior part of the tooth. M1 has a strong lingual cingulum.

Discussion: For the differences from Amphicyon, see discussion above. The material from Sandelzhausen differs from Cynelos and Ysengrinia (Kuss 1965) in having no accessory cusps on the premolars, a shorter talonid in $\mathrm{m} 1$, and a noncutting hypoconid. Additionally, Cynelos carries cusplets on the lingual part of the $\mathrm{m} 1$ talonid, which is not present among the Sandelzhausen material.

No $\mathrm{m} 1$ from Sandelzhausen has a strong hypoconid and the entoconid is not elongated as in P. bavaricus beaucensis. The metaconid is placed slightly further back than the protoconid and no cusps are developed in the lingual part of the $\mathrm{m} 1$ talonid as is the case in P. bavaricus bavaricus. Metrically, the $\mathrm{m} 1$ from Sandelzhausen fits well within the size range given for P. bavaricus, in particular the subspecies pontignensis from the Faluns de l'Anjou, France (Ginsburg 1992) (Fig. 5). The lower $\mathrm{m} 1$ from Baigneaux (France) assigned to $P$. b. beaucensis, and from Flinz (Germany) assigned to P. b. bavaricus by Ginsburg (1992), are also comparable in size.

Pseudarctos bavaricus is known from only a few remains in Central Europe from MN5 to MN8 (Werdelin 1996) and has been recorded from, e.g., Göriach, Austria (Helbing 1936), Sansan (Ginsburg 1961), and Häder (Schlosser 1899). The material falls within P. b. pontignensis. However, based on the few known specimens, it remains unclear whether the subspecies represents a systematically separate taxon or just variability within P. bavaricus (Table 3). 


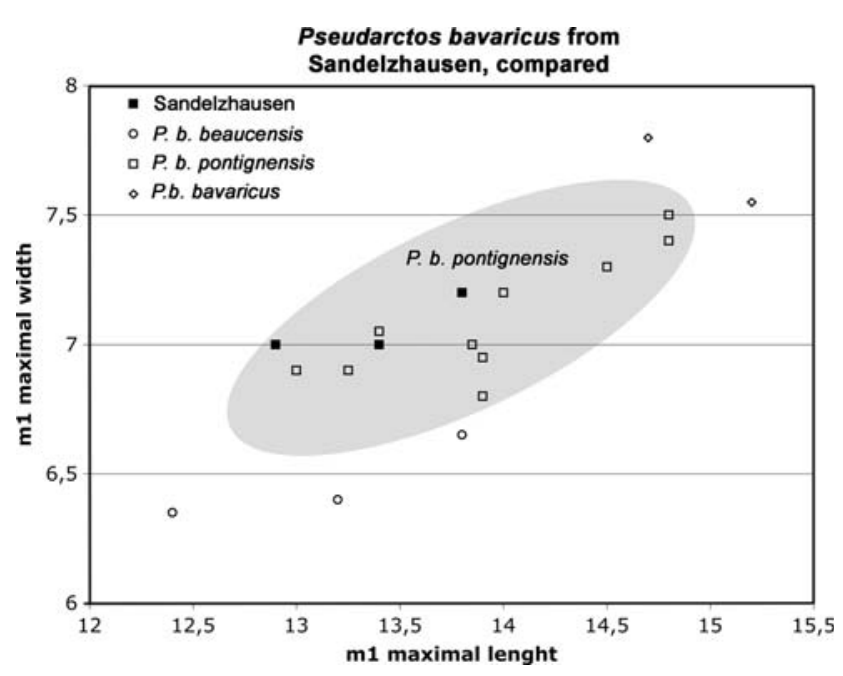

Fig. 5 Scatter diagram of $\mathrm{m} 1$ from Pseudarctos bavaricus, different subspecies compared [comparative measurements after Ginsburg (1992)]. Each point represents an individual specimen

Table 3 Teeth measurements (mm) from Pseudarctos bavaricus Schlosser, 1899

\begin{tabular}{llllll}
\hline Coll. no. & Element & $\begin{array}{l}\text { Max. } \\
\text { length }\end{array}$ & $\begin{array}{l}\text { Max. } \\
\text { width }\end{array}$ & $\begin{array}{l}\text { Trigonid } \\
\text { length }\end{array}$ & $\begin{array}{l}\text { Trigonid } \\
\text { width }\end{array}$ \\
\hline 8238 & M1 sin & 7.8 & 12.4 & & \\
8060 md dext & $\mathrm{p} 4$ & 8.0 & 4.1 & & \\
$8060 \mathrm{md}$ dext & $\mathrm{m} 1$ & 13.4 & $(7)$ & 8.7 & 7.0 \\
$8061 \mathrm{md} \sin$ & $\mathrm{p} 4$ & 8.4 & 4.5 & & \\
$8061 \mathrm{md} \sin$ & $\mathrm{m} 1$ & 13.8 & 7.2 & 9.2 & 6.5 \\
$8061 \mathrm{md} \sin$ & $\mathrm{m} 2$ & 9.6 & 7.1 & & \\
$8061 \mathrm{md} \sin$ & $\mathrm{m} 3$ & 7.5 & 5.8 & & \\
8081 sin & $\mathrm{m} 1$ & 12.9 & 7.0 & 8.5 & 6.4 \\
5295 & $\mathrm{~m} 3$ & 8.7 & 6.8 & & \\
16203 & $\mathrm{~m} 3 \sin$ & $(7.4)$ & $(6.1)$ & & \\
\hline
\end{tabular}

Specimens in brackets represent broken

Family Ursidae Gray, 1825.

Subfamily Hemicyoninae Frick, 1926.

Genus Hemicyon Lartet, 1851.

Type species: Hemicyon sansaniensis Lartet, 1851.

The Hemicyoninae were characterized by Frick (1926) as ursids lacking the M3. Several revisions of the subfamily were undertaken (Huerzeler 1944, Ginsburg 1955, and Ginsburg and Morales 1998). Cephalogale (Jourdan 1862) is considered the most plesiomorphic member of the Hemicyoninae (Ginsburg and Morales 1998a, b; Hunt 1998). According to Ginsburg and Morales (1998a, b), the Hemicyoninae consists of the genera Zaragocyon (Ginsburg and Morales 1995), Hemicyon, and Dinocyon (Jourdan 1861) only, while Plithocyon (Ginsburg 1955), Phoberocyon (Ginsburg 1955), and Phoberogale (Ginsburg and Morales 1995) are placed in a separate subfamily, the Phoberocyoninae. Phoberocyon and probably Phoberogale show an increasing tendency toward carnivory and are therefore clearly distinct from Hemicyon. The separation at the genus level is justified but a differentiation as a subfamily would create unfounded taxonomic complexity. Plithocyon and Hemicyon are morphologically more similar, which sheds some doubt on the necessity to separate these genera into different subfamilies. We prefer to place all the cited genera into the subfamily Hemicyoninae, thereby omitting the subfamily Phoberocyoninae (Ginsburg and Morales 1998a, b; Nagel 2003).

Hemicyon was established by Lartet (1851) on the basis of material coming from the locality of Sansan. After some taxonomic problems it was re-established by Ginsburg (1955). It is characterized by a strong lingual cingulum on the square-shaped upper molars. The medial crest on the upper molars is derived, being elongated with a reduced protocone. The protocone of $\mathrm{P} 4$ is situated close to the paracone.

The other hemicyonine genera (except Phoberocyon, Phoberogale discussed above) differ as follows: Dinocyon is the largest hemicyonine known so far and differs in this respect clearly from the Sandelzhausen material. Zaragocyon is smaller in size and has a bigger and nondetached protocone in P4. Plithocyon has a small parastyle developed in P4, which is absent in the Sandelzhausen material. We therefore assign the material from Sandelzhausen to the genus Hemicyon.

Hemicyon stehlini.

Hürzeler, 1944.

*1944 Hemicyon stehlini Hürzeler: fig. 10-12.

"Hemicyon" stehlini Hürzeler, 1944 has always been referred to Hemicyon, but shows dental characters typical for Plithocyon (see above) and therefore was assigned to the latter genus by Heizmann (1973), and accepted by Werdelin (1996). Ginsburg and Morales (1998a, b) still used the genus Hemicyon in their summary of the European Hemicyoninae and also in Astibia et al. (2000); the authors address the material as Hemicyon.

Material: 8032: skull fragment with left alveoli of I2 and $\mathrm{I} 3, \mathrm{C}, \mathrm{P} 1$, root fragments of P2-3, P4-M2 and right alveolus for I2, M1-M2 (Fig. 13a); 8084: right M2; 2234: left M2; 8033: right mandible with root fragments of $\mathrm{c}$ inf., alveolus of p2, p3-m3 (Fig. 13b-d); 8034: left mandible with $\mathrm{p} 3-\mathrm{m} 2 ; 8045$ : isolated right $\mathrm{m} 1 ; 8046$ : left $\mathrm{m} 2 ; 8047$ : right $\mathrm{m} 2$; 8174: left astragalus; 8171: right astragalus; 8252: left calcaneus; 8180: juvenile right Mc2; 8172: right Mc3; 8192: juvenile right Mc5.

Description: The upper canine is slightly flattened and the P1 is a peg-like tooth. The P3 is small and reduced with a main cusp almost equal in size to the posterior part of the cingulum and no anterior cusp. A small cingulum is visible 
at the posterior part. The protocone of $\mathrm{P} 4$ is placed as posterior as the paracone. It is small, almost elongated, and detached from the main cusp by a small notch. The metastyle blade is shorter than the paracone (blade $6.6 \mathrm{~mm}$; paracone $11.3 \mathrm{~mm}$ ); no parastyle is developed. The cingulum is not very strong on its buccal side and not very visible on the lingual side due to of the state of preservation. The P3 is about half the size of P4. M1 is trapezoid, with a paracone better developed than the metacone. The protocone and metastyle form a crest; the cingulum is strong on the buccal side and forms a cusp on its lingual part. M2 is square-shaped with the paracone being the main cusp. Protocone and metastyle form a sinusshaped crest, but the protocone is not as well developed as in M1. The tooth is surrounded by a pronounced cingulum, which forms a cusp on the anterior side of the tooth.

The p3 is slender with no accessory cusps. The p4 carries a distinct crest at its anterior part and a small accessory cusp on the linguo-posterior side of the main cusp. A cingulid is present but weak on its lingual side. The $\mathrm{m} 1$ is elongated with a trigonid (19.4 mm length) more than double the size of the talonid $(8.7 \mathrm{~mm})$. The metaconid is posterior to the protoconid. The talonid is formed by a low hypoconid on the buccal side with a very small entoconid and entoconulid on the lingual side. The trigonid of $\mathrm{m} 2$ bears a protoconid and a slightly smaller metaconid. No trace of a paraconid is visible. The talonid is elongated and basined. A swelling on its lingual side might represent the remnant of a former hypoconid.

Comparison: Despite the well-preserved material, the question whether stehlini belongs to Plithocyon or Hemicyon is still open. The material from Sandelzhausen shows a mixture of characters. The $\mathrm{P} 4$ has an elongated protocone at about the same level as the paracone, the M1 is trapezoid and has no flat inner basin as described by Heizmann (1973) for the stehlini specimen from Engelswies (Germany, MN5), and the metaconid on $\mathrm{m} 1$ is more posterior than the protoconid. All these characteristics are typical for the genus Hemicyon. Additionally, the M1 has a larger paracone than metacone and the M2 is rectangular with a weak developed metacone and the protoconid and metaconid on $\mathrm{m} 2$ are of equal size. These characteristics are typical for the genus Plithocyon (Heizmann 1973, Ginsburg and Morales 1998a, b). Therefore a clean assignment to one of the two genera is still difficult and we prefer to keep the name given by Huerzeler (1944): Hemicyon stehlini. This species is known from France, Germany, and probably from Czech Republic (Huerzeler 1944, Ginsburg and Bulot 1982, Heizmann 1973, Roth 1989, Fejfar et al. 2003).

$H$. stehlini is intermediate in size between $H$. gargan (Ginsburg and Morales 1998), H. sansaniensis (Lartet 1851), and H. goeriachensis (Toula 1884), respectively.
The amount of variation of the $\mathrm{m} 2$ trigonid concerning development of protoconid and metaconid represents an ancestral feature, similar to the pattern in $H$. sansaniensis and H. goeriachenis (Ginsburg and Morales 1998a, b). $H$. goeriachensis is almost equal in size to $H$. sansaniensis and is more common in Central Europe from MN6 to MN9. $H$. sansaniensis is more abundant in Western Europe from MN5 to MN6 (Werdelin 1996, Ginsburg 1999, Nagel 2003).

H. sansaniensis from MN6 (Sansan) is larger and differs in several morphological details. In M2, the protocone is smaller than the metacone. The $\mathrm{P} 4$ has a smaller protocone, which is placed further back, while no cusps are developed on the anterior cingulum. In $\mathrm{m} 2$, the protoconid is larger than the metaconid while on the Sandelzhausen specimens the two cusps are of equal size. H. goeriachensis is interpreted as being more advanced (Heizmann 1973). Its teeth are more elongated due to the weaker cingulids. The protoconid of $\mathrm{m} 2$ is smaller than the metaconid. H. gargan is the smallest known species of Hemicyon to date. The protocone of $\mathrm{P} 4$ has a more labiad insertion, is more pronounced, while a small crest connects the metacone with the metaconule of M1. H. mayorali (Astibia et al. 2000) from MN4 (Tarazona de Aragón, Spain), the largest species of Hemicyon species known so far, differs from the Sandelzhausen specimen in size, in the lack of any anterolingual crest in P4, and in having M2 oriented less obliquely in relation to the long axis of the tooth row. Hemicyon teilhardi (Huerzeler 1944) is larger than Hemicyon from Sandelzhausen. Furthermore, the protocone of $H$. teilhardi is situated very far back, a unique character among hemicyonines (Colbert 1939).

H. stehlini is known in Europe from France (Pontlevoy, Baigneaux, Bézian, Pellecahus, Montréal-du-Gers, Travers), Spain (Buñol), Portugal (Quinta da Barbacena, Quinta da Conceicao, Quinta do Pombeiro), and Germany (Engelswies, Stätzling, Georgensgmünd) (Heizmann 1973; Roth 1989). An overview can be found in Ginsburg and Morales (1998a, b). Stratigraphically, the material comes from the lower Middle Miocene (MN4-MN5) (Table 4).

Family Mustelidae (Fischer, 1817) Swainsson, 1835.

Subfamily Guloninae (Gray, 1825) Miller, 1912.

Genus Ischyrictis Helbing, 1930.

Type species: Viverra zibethoides Blainville, 1842.

Within the large Middle Miocene mustelids of Europe, Ginsburg (1999) distinguishes three basic lineages: Trochictis, Iberictis, and Ischyrictis. The latter is characterized by a round lingual side of M1. Qiu (2003) summarized the stratigraphic occurrence of Ischyrictis in Europe from MN3 to MN9. Within the genus Ischyrictis three subgenera are often separated: Ischyrictis (Ischyrictis), Ischyrictis (Laphictis), and Ischyrictis (Hoplictis) (Schmidt-Kittler 1976, Ginsburg 1999). I. zibethoides is referred to the 
Table 4 Teeth measurements (mm) from Hemicyon stehlini Huerzeler, 1936

\begin{tabular}{|c|c|c|c|c|c|}
\hline Coll. no. & Element & $\begin{array}{l}\text { Max. } \\
\text { length }\end{array}$ & $\begin{array}{l}\text { Max. } \\
\text { width }\end{array}$ & $\begin{array}{l}\text { Trigonid } \\
\text { length }\end{array}$ & $\begin{array}{l}\text { Trigonid } \\
\text { width }\end{array}$ \\
\hline 8032 max & M1 & 17.9 & 20.1 & & \\
\hline $8032 \max$ & M2 & 14.3 & 18.0 & & \\
\hline $8032 \max$ & $\mathrm{C}$ & 12.7 & 8.5 & & \\
\hline $8032 \max$ & P1 (?) & 7.9 & 3.0 & & \\
\hline $8032 \max$ & $\mathrm{P} 4$ & 20.0 & 10.4 & & \\
\hline $8032 \max$ & P3 & & & & \\
\hline $8032 \max$ & M1 & - & & & \\
\hline $8032 \max$ & M2 & 14.0 & 19.0 & & \\
\hline 8084 & M2 dext & 17.1 & - & & \\
\hline $8033 \mathrm{md} \sin$ & p3 & 9.6 & 4.4 & & \\
\hline $8033 \mathrm{md} \sin$ & $\mathrm{p} 4$ & 12.6 & 6.4 & & \\
\hline $8033 \mathrm{md} \sin$ & $\mathrm{m} 1$ & 28.2 & 11.5 & 19.5 & 9.9 \\
\hline $8033 \mathrm{md} \sin$ & $\mathrm{m} 2$ & 17.3 & 10.6 & & \\
\hline 8033 md sin & $\mathrm{m} 3$ & 9.9 & 8.5 & & \\
\hline 8034 md dext & $\mathrm{p} 3$ & 9.5 & 4.1 & & \\
\hline 8034 md dext & $\mathrm{p} 4$ & $(13.1)$ & 6.2 & & \\
\hline 8034 md dext & $\mathrm{m} 1$ & 27.5 & 11.4 & 19.0 & 9.3 \\
\hline 8034 md dext & $\mathrm{m} 2$ & 18.0 & 11.4 & & \\
\hline 8045 & $\mathrm{~m} 1 \mathrm{dext}$ & 27.9 & 11.5 & 29.6 & 10.5 \\
\hline 8047 & $\mathrm{~m} 2$ dext & 17.4 & 11.6 & & \\
\hline 8046 & $\mathrm{~m} 2 \sin$ & 17.2 & 11.8 & & \\
\hline
\end{tabular}

Specimens in brackets represent broken

subgenus Ischyrictis, I. mustelinus to the subgenus Laphictis (Crusafont 1972, Heizmann 1973, Roth 1989), and I. anatolicus from Çandir (Turkey, MN5) to the subgenus Hoplictis (Schmidt-Kittler 1976; Nagel 2003). The latter assignment to the subgenera is followed herein.

Ischyrictis (Ischyrictis) zibethoides (Blainville, 1842).

*1842 Viverra zibethoides Blainville: pl. VI fig. 1-15.

1859 Amphicyon zibethoide (Blainville, 1842) - Gervais: pl. XXVIII fig. 13.

1891 Mustela zibethoides (Blainville, 1842)_Filhol: 98.

1930 Ischyrictis zibethoides (Blainville, 1842)—Helbing: 637.

Material: 8246: maxillar fragment with right P3; 8044: left P4 (Fig. 13p-r), right M1 (Fig. 13n), left M1 broken (Fig. 13o); 8080: right P4, protocone missing; 8059: right $\mathrm{P} 4$, protocone missing; 8085: left $\mathrm{P} 4$, protocone missing; 8072: right M1, layer C; 8073: left M1, layer C; 8083: right P4-fragment; 8037: left lower jaw, most complete specimen, with c-m1, alveolus of $\mathrm{m} 2$, layer C (Fig. 13h-j); 8038: left lower jaw, distal part of ramus well preserved, with p1-m1, alveolus of $\mathrm{m} 2$ layer B; height of coronoid process $58.3 \mathrm{~mm}$; 8039: right lower jaw fragment with broken roots of $\mathrm{p} 3-\mathrm{p} 4, \mathrm{~m} 1$, alveolus of $\mathrm{m} 2$, layer $\mathrm{B} ; 40$ : right lower jaw fragment with $\mathrm{m} 1$; 8040: left lower jaw fragment with alveolus of p1, p2-m1, layer B (Fig. 13e-g); 8041: right lower jaw fragment with alveoli of $\mathrm{c}$ inf. and p1, p2-m1, alveolus of m2; 8042: left lower jaw fragment with p4-m1, alveolus of $\mathrm{m} 2$, layer B; 8086: left lower jaw with alveolus of p1, p3-p4, m1 broken; 8043: right lower jaw fragment with broken $\mathrm{p} 3, \mathrm{p} 4$, proximal part of $\mathrm{m} 1$ and alveolus of $\mathrm{m} 2 ; 8049$ : right lower jaw fragment with p2-p4, layer B/C; 8234: left p4; 8235: left p4; 8149: right astragalus; 8236: right p3. 8254: left astragalus; 8255: left astragalus fragment; 8168: left calcaneus; 8251: left calcaneus; 8353: left calcaneus; 8141: right metatarsal 3; 8343: left metatarsal 3 proximal part.

Description: One mandible is nearly complete (8037), with $\mathrm{c}-\mathrm{m} 1$ in place and the condylus and most of the coronoid process preserved. The massetric fossa is a deep groove starting with a clear rim ventral to $\mathrm{m} 2$. Ventrally, the mandibular ramus is straight.

The premolars are spaced with the wider diastemes between p2 and p3 (1.5-4.2 mm) and the lesser between p3 and p4 (0.5-0.9 mm). As is typical for Ischyrictis, p1 is a very small, peg-like, slightly flattened tooth, which is much smaller than p2-4. These increase progressively in size and also progressively add an anterior and posterior cingulid. The first three premolars carry no anterior or posterior cusps. In p2, the main cusp is rotated anteriorly, in p3 it is placed more in the centre, and in p4 the protocone is slightly retrorse. The $\mathrm{p} 4$ bears a posterior accessory cusp and is surrounded by a cingulid at its anterior part. The tips of the main cusps in p2-p4 are all blunt and rounded, mostly with little wear; p4 usually shows more wear than the other premolars. All premolars except p1 display a small ridge in the midline.

The length of the $\mathrm{m} 1$ trigonid is about two-thirds of the overall tooth length with the protoconid being the highest cusp. The metaconid is distinctly lower than the protoconid. It is as high as the paraconid and placed close to the protoconid. The talonid is low and surrounded by a cingulid. Two different talonid morphologies can be observed among the material from Sandelzhausen. Three molars $(8039,8037$, and 8042) have a relatively flat talonid, which is encircled by a well-developed cingulid, extending from the base of the protoconid to the base of the metaconid. Along the midline of the talonid is a noticeable though minor crest (most pronounced in 8037), but no additional cusp such as a hypoconid or entoconid can be observed (Fig. 13h-j). A similar morphology is present in I. zibethoides from Sansan [depicted by Filhol (1891): pl. VI], while the material described and depicted by Ginsburg (1961) mainly has a hypoconid. Four other lower molars from Sandelzhausen (8038, 8041, and 8040) show a well-developed cingulid around the talonid and a welldeveloped hypoconid (40: Fig. 13k-m). All $\mathrm{m} 1$ are of 
Fig. 6 Scatter diagram of lower dentition of Hemicyon stehlini from Sandelzhausen, compared [comparative measurements from Ginsburg (1965) and Ginsburg and Morales (1998)]. Each point represents an individual specimen

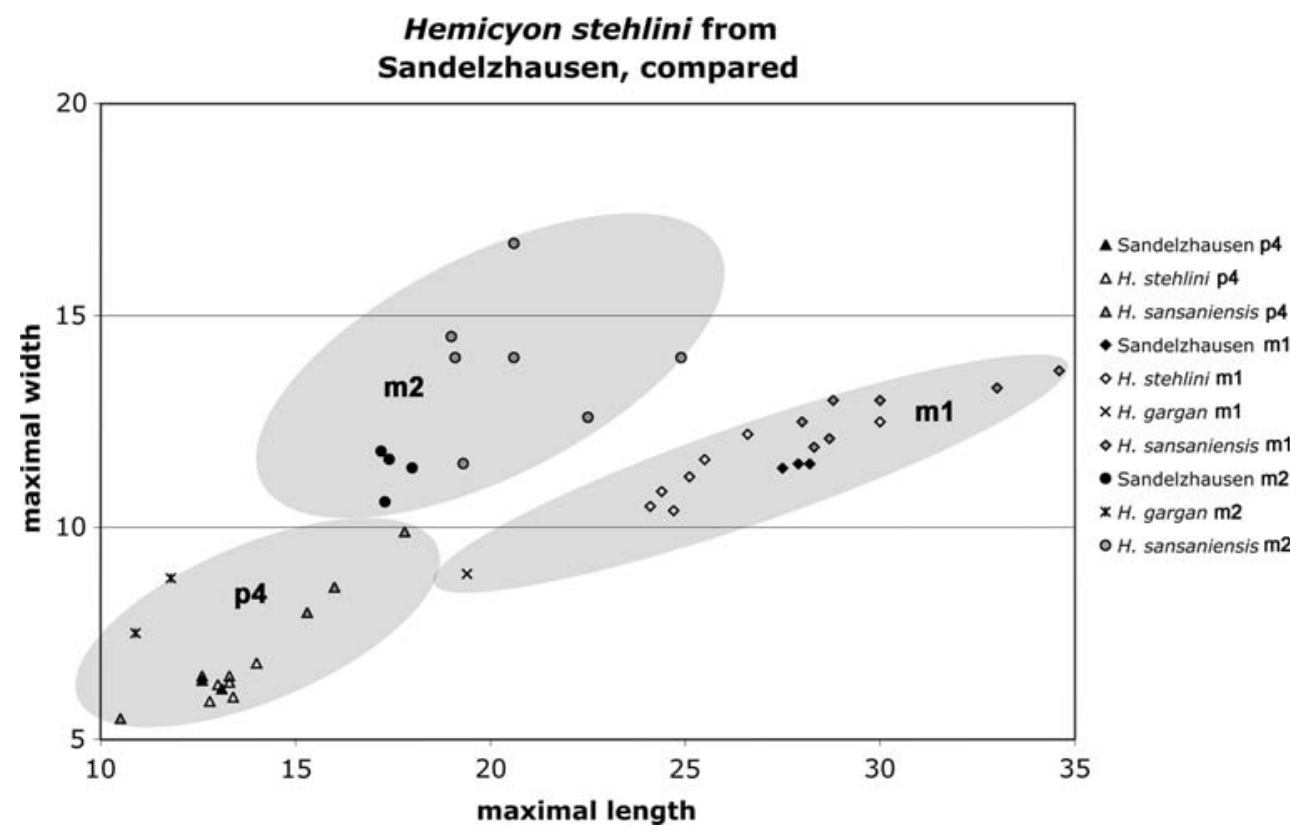

similar size; only one lower molar is more massive and larger than the others (40: Figs. 4k-m, 7).

The upper carnassial has a slender, elongated cutting blade. The protocone is placed more lingually and connected to the protocone through a relatively narrow neck. This lingual projection of the protocone is the reason for the large breadth of the tooth, whereas the cutting blade itself is much more slender. The breadth of $\mathrm{P} 4$ posterior to the protocone is only about $6-7 \mathrm{~mm}$, compared with $11-12 \mathrm{~mm}$ of maximum breadth. The parastyle is developed only as a low tip, formed by the cingulum. It is connected to the protocone by a slight rim.

All preserved M1 are transversely elongated, fairly flat, and display different amounts of wear. Paracone, metacone, the lingual protocone, and the elevated lingual cingulum are about equally pronounced. In the trigon the paracone is predominant. It takes up about three-quarters of the space and is more pronounced than the metacone. The metacone is connected to the paracone by a crest, which is cut by a deep narrow trough. The marked cingulum on the buccal outer rim of the M1 also shows a clear notch between paracone and metacone. Both paracone and metacone show a short and steep decline lingually toward the talon, but there is a narrow, crest-like line connecting paracone and protocone. No metaconule or paraconule is developed (Fig. 6).

Discussion and comparisons: Ginsburg (1999) described an evolutionary sequence from I. bezianensis Ginsburg and Bulot, 1982 from Bézian (France, MN4b), to I. zibethoides (Blainville 1842) from Sansan (France, MN6) to I. mustelinus (Viret 1933) from Steinheim (Germany, MN7) and La Grive-Saint-Alban (France; mostly MN7/8, but including faunal elements from MN5, see below).
The material of I. (I.) zibethoides from Sandelzhausen represents the most numerous material of this species from a single locality so far. From Sansan, a good set of mandibles from (I.) zibethoides were described (Ginsburg 1961; Roth 1989), but only a little is known about the upper dentition. Thus, the Sandelzhausen material allows a better understanding of the variability in size and form of the individual teeth. For the first time two morphological variations of the talonid are described for Ischyrictis (I.) zibethoides. The occurrence of this variation is not correlated with a specific stratigraphic layer in the section and thus does not represent an evolutionary difference. Instead, it is interpreted as intraspecific variation. This is corroborated by the otherwise morphological and metrical uniformity of the teeth.

In Ischyrictis three evolutionary lines have been recognized as subgenera so far: Hoplictis, Laphictis, and Ischyrictis. Hoplictis was described with a felinoid tendency (Ginsburg 1961; Ginsburg and Morales 1992). I. (H.) floriancei (Mayet 1908) was described from Thenay (France, MN5), and Ischyrictis (H.) anatolicus (Schmidt-Kittler 1976) is endemic in Anatolia (Nagel 2003). The carnassials tend more toward hypercarnivory, with the protocone of $\mathrm{P} 4$ being smaller and not projecting lingually and anteriorly and the crest-like hypoconid of $\mathrm{m} 1$ being inserted more centrally on the talonid. Furthermore, the metaconid of the lower molars is higher and more detached from the protoconid. Diastemes between the lower premolars are not present, but these premolars carry posterior cusps. Metrically, $\mathrm{m} 1$ of I. (H.) anatolicus and I. (I.) zibethoides are very similar in length and width, with I. anatolicus being slightly smaller (Figs. 7, 8). 
Fig. 7 Scatter diagram of lower dentition of $I$. (I.) zibethoides from Sandelzhausen, compared [comparative measurements from Helbing (1930), Ginsburg (1961), Heizmann (1973), and Roth (1989)]. Each point represents an individual specimen

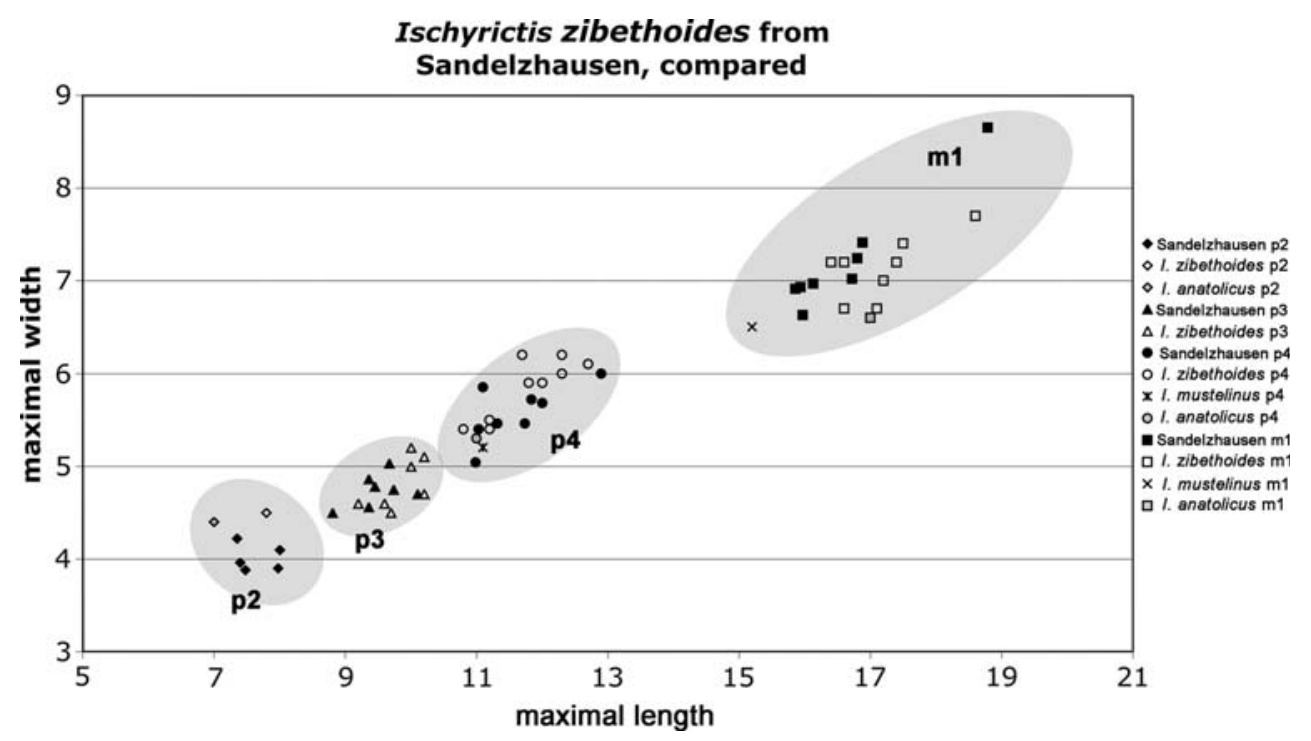

The subgenus Laphictis was erected as a genus (type species Laphictis mustelinus) by Viret (1933) from La Grive-Saint Alban (France), but Helbing (1936) placed this genus in the Ischyrictis group. Dehm (1950) assigned the material from Winterhof-West to $I$. (L.) mustelinus and reported the missing $\mathrm{p} 1$ as an autapomorphy. Ginsburg and Morales (1992) assigned this species to a new genus, Dehmictis.

Helbing (1930) noted for Ischyrictis (L.) mustelinus from Steinheim a hypoconid, which is steeper lingually than buccally. This is different from I. (I.) zibethoides from Sandelzhausen where the hypoconid, if present, is symmetrically shaped. The $\mathrm{m} 1$ of $I$. (L.) mustelinus described by Viret (1951) from La Grive-Saint-Alban has a higher talonid than that from the Sandelzhausen material. In I. (L.) mustelinus the mandibular teeth are closer together, leaving only a narrow gap between p2 and p3. Also in p4 the second cusp attached to the protoconid seems to be more strongly developed (Helbing 1936, fig. 6). Roth (1989) mentioned three foramina mentalia in contrast to only two in I. zibethoides. In general, I. (L.) mustelinus is a bit smaller in size (Fig. 7).

I. bezianensis (Ginsburg and Bulot 1982) from Bezian is only known by one upper M1 which bears a metaconule. This is not the case in any Sandelzhausen M1. The specimen from Bezian was not assigned to any of the subgenera but was described as being more similar to the Laphictis group by the authors.

Ischyrictis is known from Europe from MN3 to MN9. It also occurs in North America (Qiu 2003). Ischyrictis (I.) zibethoides has been recorded from Western Europe (Spain, France, Germany) only, whereas I. (H). anatolicus has been found only in Turkey (Pasalar, Çandir). This might indicate a different geographic distribution of the subgenera Ischyrictis and Hoplictis (Tables 5, 6).
Fig. 8 Ischyrictis zibethoides (Blainville, 1842) from Sandelzhausen. 8072: right M1 
Table 5 Postcranial measurements (mm) from Hemicyon stehlini Huerzeler, 1936

\begin{tabular}{|c|c|c|c|c|c|c|c|c|}
\hline Coll. no. & \multicolumn{2}{|c|}{ Element } & Total length & \multicolumn{3}{|c|}{ Total width } & & \\
\hline 8174 & \multicolumn{2}{|c|}{ atragalus sin } & 42.0 & \multicolumn{2}{|l|}{30.0} & & & \\
\hline 8171 & \multicolumn{2}{|c|}{ atragalus dext } & - & \multicolumn{2}{|l|}{$(24.5)$} & & & \\
\hline 8252 & \multicolumn{2}{|c|}{ calcaneus sin } & 53.7 & \multicolumn{2}{|l|}{24.2} & & & \\
\hline Coll. no. & Element & $\begin{array}{l}\text { Total } \\
\text { length }\end{array}$ & $\begin{array}{l}\text { Length } \\
\text { proximal } \\
\text { ant/post }\end{array}$ & $\begin{array}{l}\text { Width } \\
\text { proximal } \\
\text { lat/med }\end{array}$ & $\begin{array}{l}\text { Length } \\
\text { distal } \\
\text { ant/post }\end{array}$ & $\begin{array}{l}\text { Width } \\
\text { distal } \\
\text { lat/med }\end{array}$ & $\begin{array}{l}\text { Diaphysis } \\
\text { lateral }\end{array}$ & $\begin{array}{l}\text { Diaphysis } \\
\text { medial }\end{array}$ \\
\hline 8180 & Mc2 dext & - & 15.2 & 10.1 & & & 8.1 & 6.2 \\
\hline 8172 & Mc3 dext & 74.7 & 15.6 & 12.4 & 12.2 & 14.9 & 8.4 & 7.2 \\
\hline 8192 & Mc5 dext & - & 16.8 & 13.6 & & & 8.8 & 7.2 \\
\hline
\end{tabular}

Specimens in brackets represent broken

Genus Martes Pinel, 1982.

Type species: Martes fiona (Linneum, 1758).

Martes cf. munki Roger, 1900.

*1900 Martes munki-Roger: pl. 3 fig. 3.

1933 Martes munki Roger-Viret: 15, pl. 1 fig. 10-13. 1951 Martes munki Roger-Viret: 57, pl. 2 fig. 23.

Material (measurement in mm, length:width): 8087 : left mandible with p2 (3.8:2.1), p3 (4.7:2.3), alveoli of p4, $\mathrm{m} 1(8.4: 3,8)$ and $\mathrm{m} 2$ (3.3:3.2); 8074: fragment of right mandible with $\mathrm{m} 1$ (9.5:4.1) and alveolus of $\mathrm{m} 2$; 8108: isolated left $\mathrm{m} 1$ (9.5:4.1); 8088: right mandible with $\mathrm{p} 3$ $(4.8 \mathrm{~mm}: 2.3 \mathrm{~mm}), \mathrm{p} 4(5.8 \mathrm{~mm}: 2.7 \mathrm{~mm})$, alveolus of anterior part of $\mathrm{m} 1$ and $\mathrm{m} 1$ talonid; 8133: fragment of left mandible with damaged $\mathrm{p} 2, \mathrm{p} 3$ (5.5:2.2); 8078: fragment of right maxilla with alveolus of $\mathrm{P} 1, \mathrm{P} 2$, fragment of $\mathrm{P} 3$, anterior alveolus of P4; 8112: isolated left P3 (5.0:2.1).

Description and comparisons: The specimens fit extremely well with the description of the species by, e.g., Stehlin and Helbing (1925), Viret (1951), and Ginsburg and Bulot (1982). It differs from the similar M. sainjoni (Mayet 1908) by a relatively long talonid. All Sandelzhausen specimens, however, are about 5-10\% larger than previously described material of M. munki. We therefore refer the Sandelzhausen record only tentatively to M. munki.

Discussion: Martes munki is well known from MN4-5 in Europe (NOW) but also occurs in La Grive (France, traditionally placed in MN7/8, but see remarks below), Häder (Germany, MN5), and Pontlevoy (France, MN5) (Roger 1900; Stehlin and Helbing 1925; Viret 1951).

Family Mephitidae (Bonaparte, 1845).

Genus Proputorius Filhol, 1891.

Type species: Proputorius sansaniensis Filhol, 1891.

Proputorius pusillus (Viret, 1951).

*1951 Martes pusilla Viret: 58-60, fig. 11-13, pl. 2 fig. 24-25.

Material: 8136: fragment of right mandible with $\mathrm{m} 1$ $(5.2 \mathrm{~mm}: 2.2 \mathrm{~mm})$ and alveolus of $\mathrm{m} 2$. A couple of very small premolars also belong to the realm of Sandelzhausen carnivorans, but their unspecialized morphology does not allow an assignment, even if they may belong to $P$. pusillus, if only judging by size.

Description: In the very small $\mathrm{m} 1$, the trigonid consists of the dominant protoconid, the paraconid, which reaches about two-thirds of the height of the protoconid, and a small metaconid, which is placed slightly further back than the protoconid, from which it is separated by a little notch. The carnassial blade reaches the same height as the protoconid throughout its length. A short carnassial notch is developed. The talonid reaches a length of $2.0 \mathrm{~mm}$. It is dominated by the hypoconid and has a little wall developed at its posterior and lingual margin which creates a very shallow basin. Cingulids are completely missing.

Discussion: This tiny Martes-like specimen differs from most other Middle Miocene musteloids (including Martes munki) by its small size. The only taxon of comparable size and morphology is P. pusillus (Viret 1951, figs. 11-13), even though the carnassial blade of the holotype does not extend to the same height as the protoconid but slopes down posteriorly. This difference, however, is caused by the high abrasion the holotype underwent, while the Sandelzhausen tooth is rather fresh. Besides size, the $\mathrm{m} 1$ differs from the slightly larger Martes delphinensis Depéret, 1892 in having the metaconid separated from the protoconid by a notch and having a relatively longer talonid. These characters also allow the separation of the taxon from Mustelidae and a placement into the Middle Miocene mephitid genus Proputorius. The holotype was described from La Grive-Saint-Alban (France), which generally is regarded to be MN7/8 in age (e.g., Ginsburg 1999). The presence of the gigantic hyaenodontid Hyainailouros and the gulonine Martes munki (see below), however, indicates that faunal elements of MN5 are present in the assemblage of La Grive as well. The occurrence of $P$. pusillus in MN5 of Sandelzhausen is therefore no surprise.

Suborder Feliformia Kretzoi, 1945. 
Table 6 Teeth measurements (mm) from Ischyrictis (I.) zibethoides (Blainville, 1842)

\begin{tabular}{|c|c|c|c|c|c|c|}
\hline Coll. no. & Element & Total length & Total width & $\begin{array}{l}\text { Length metastyle } \\
\text { blade }\end{array}$ & $\begin{array}{l}\text { Width metastyle } \\
\text { blade }\end{array}$ & \\
\hline \multicolumn{7}{|l|}{ Upper dentition } \\
\hline 8236 & P3 dext & 11.5 & 6.5 & & & \\
\hline 8044 & $\mathrm{P} 4 \sin$ & 6.5 & 11.0 & & 6.6 & \\
\hline 8044 & M1 dext & 9.0 & 15.5 & & & \\
\hline 8059 & P4 dext & 14.0 & 7.9 & & 4.6 & \\
\hline 8080 & P4 dext & 14.9 & - & & 6.5 & \\
\hline 8083 & P4 dext & $(13.2)$ & - & & 6.4 & \\
\hline 8085 & $\mathrm{P} 4 \sin$ & 16.0 & - & & 6.3 & \\
\hline 8073 & M1 sin & 7.6 & 14.4 & & & \\
\hline 8072 & M1 dext & 9.1 & 16.3 & & & \\
\hline Lower dentition & & Total length & Total width & Trigonid length & Trigonid width & Height \\
\hline $8037 \mathrm{md}$ sin & $\mathrm{p} 1$ & 4.1 & 2,7 & & & \\
\hline $8037 \mathrm{md}$ sin & $\mathrm{p} 2$ & 7.4 & 4.0 & & & 5.6 \\
\hline $8037 \mathrm{md}$ sin & p3 & 9.4 & 4.9 & & & 5.1 \\
\hline $8037 \mathrm{md}$ sin & $\mathrm{p} 4$ & 11.3 & 5.5 & & & 6.9 \\
\hline $8037 \mathrm{md}$ sin & $\mathrm{m} 1$ & 15.9 & 6.9 & 10.3 & 6.2 & 8.9 \\
\hline $8038 \mathrm{md}$ sin & $\mathrm{p} 1$ & 3.2 & 3.0 & & & 3.3 \\
\hline $8038 \mathrm{md}$ sin & $\mathrm{p} 2$ & 7.5 & 3.9 & & & 4.7 \\
\hline $8038 \mathrm{md}$ sin & p3 & 9.4 & 4.6 & & & 5.0 \\
\hline $8038 \mathrm{md}$ sin & $\mathrm{p} 4$ & 12.0 & 5.7 & & & 4.7 \\
\hline $8038 \mathrm{md} \sin$ & $\mathrm{m} 1$ & 16.8 & 7.2 & 11.3 & 6.2 & 8.2 \\
\hline 8039 md dext & $\mathrm{m} 1$ & 16.7 & 7.0 & 12.0 & 5.9 & 7.4 \\
\hline $8040 \mathrm{md} \sin$ & $\mathrm{p} 2$ & 7.4 & 4.2 & & & 4.3 \\
\hline 8040 md sin & p3 & 9.7 & 5.0 & & & 5.3 \\
\hline 8040 md sin & $\mathrm{p} 4$ & 11.1 & 5.9 & & & 6.5 \\
\hline $8040 \mathrm{md} \sin$ & $\mathrm{m} 1$ & 16.1 & 7.0 & 10.9 & 6.3 & 9.0 \\
\hline 8041 md dext & p2 & 7.9 & 3,9 & & & 4.3 \\
\hline 8041 md dext & p3 & 9.5 & 4.8 & & & 5.0 \\
\hline 8041 md dext & $\mathrm{p} 4$ & 11.8 & 5.7 & & & 6.6 \\
\hline 8041 md dext & $\mathrm{m} 1$ & 16.9 & 7.4 & 12.1 & 5.9 & 8.2 \\
\hline $8042 \mathrm{md}$ sin & $\mathrm{p} 4$ & 11.0 & 5.0 & & & 5.4 \\
\hline $8042 \mathrm{md}$ sin & $\mathrm{m} 1$ & 15.9 & 6.6 & 10.9 & 6.0 & 6.7 \\
\hline 8049 md dext & p2 & 8.0 & 4.1 & & & \\
\hline 8049 md dext & p3 & 10.1 & 4.7 & & & \\
\hline 8049 md dext & $\mathrm{p} 4$ & 12.9 & 6.0 & & & \\
\hline $8086 \mathrm{md}$ sin & p3 & 9.7 & 4.8 & & & 4.9 \\
\hline $8086 \mathrm{md} \sin$ & $\mathrm{p} 4$ & 11.8 & 5.6 & & & 6.2 \\
\hline $8086 \mathrm{md}$ sin & $\mathrm{m} 1$ & - & & & & \\
\hline 8043 md dext & p3 & - & & & & \\
\hline 8043 md dext & $\mathrm{p} 4$ & 11.7 & 5.5 & & & 6.3 \\
\hline 8043 md dext & $\mathrm{m} 1$ & - & & & & \\
\hline $40 \mathrm{md}$ & $\mathrm{m} 1 \mathrm{dext}$ & 18.8 & 8.7 & 13.2 & 6.9 & 8.4 \\
\hline 8048 & p3 sin & 8.8 & 4.5 & - & & \\
\hline 8048 & $\mathrm{p} 4 \sin$ & 11.0 & 5.4 & & & \\
\hline 8048 & $\mathrm{~m} 1 \sin$ & 15.9 & 6.9 & 8.2 & & \\
\hline
\end{tabular}


Family Viverridae (Gray, 1825).

Genus Leptoplesictis Major, 1903.

Type species: Leptoplesictis aurelianensis (Schlosser, 1888).

Not many differences can be found between the extant Herpestes and Leptoplesictis (Major 1903), therefore this genus was not used for quite some time. Schmidt-Kittler (1987) re-established Leptoplesictis to distinguish between the fossil and the recent forms in his work about African carnivores. He described differences in the morphology such as a lower trigonid on $\mathrm{m} 2$ and higher anterior accessory cusps on $\mathrm{p} 3$ and $\mathrm{p} 4$. The details of these differences in the three fossil species are listed in Roth (1988).

Leptoplesictis cf. aurelianensis (Schlosser, 1988).

*1988 Stenogale aurelianensis-Schlosser: 153.

1907 Stenogale aurelianensis Schlosser-Stehlin: 526.

1908 Stenogale aurelianensis Schlosser-Stehlin: 223, fig. 72 .

1925 Herpestes aurelianensis Schlosser-Stehlin \& Helbing: 59, fig. 14.

1987 Leptoplesictis Schlosser-Schmidt-Kittler: 105.

1987 Leptoplesictis aurelianensis (Schlosser)—Roth: 175, fig. 137-138.

1988 Leptoplesictis aurelianensis (Schlosser)—Roth: 335, fig. 1-2.

Material: 8125: left isolated fragment of P4; 8146: left isolated fragment of P4; 9031: left M1 (2.9 mm:5.5 mm); 8132: isolated crown of $\mathrm{m} 1$ (length:width $=5.6 \mathrm{~mm}$ : $2.2 \mathrm{~mm}$ ).

Description and comparison: The M1 has a triangular shape with a pointed protocone, a well-developed paracone and metacone. The parastyle is very distant from the paracone and therefore the tooth seems elongated and slender. On the P4, only the posterior half is preserved with the paracone and the metastyle. A strong cingulum is developed on the buccal side. The lower carnassial consists of a high trigonid, where the protoconid is distinctly higher than the paraconid and the metaconid is the smallest cusp leaning posteriad. The talonid is much lower and narrower. The worn hypoconid is at the posterior end and the entoconid is very low.

Size and development of the talonid of $\mathrm{m} 1$ are typical for Leptoplesictis. In other Viverridae such as Viverrictis or Jourdanicts the talonid is characterized by three cusps, the entoconid being much larger than the other two. The material from Sandelzhausen is rather small and slender. The morphology of the talonid of $\mathrm{m} 1$ is similar to aurelianensis from La Grive (France, MN7/8) and Petersbuch 2 (Germany, MN4).

Roth (1988) revised the Leptoplesictis material and recognized three species: L. aurelianensis (Schlosser), L. filholi (Gaillard), and L. atavus (de Beaumont). Leptoplesictis filholi is characterized by its greater tooth length but in general is smaller in size (Roth 1988; Viret 1951). In contrast to aurelianensis, in L. atavus the trigonid of $\mathrm{m} 1$ is stouter, the metaconid placed more anteriad, and the talonid cusps are higher.

Leptoplesictis aurelianensis is rather rare and was known only from Spain (Hostalets de Pierola, MN7/8), France (La Grive Saint-Alban, MN7/8; Sansan, MN6; Vieux-Collognes, MN5), and Germany (Petersbuch 2, MN4; Stein/Rhein, MN6).

Family Felidae Gray, 1821.

Subfamily Felinae Trouessart, 1885.

Genus Pseudaelurus Gervais, 1850.

Type species: Pseudaelurus quadridentatus (Blainville, 1842).

Gervais (1850) erected the new genus Pseudaelurus for the Sansan material, while Ginsburg (1961) created the generic name Sansanosmilus for the barbourofelid remains from this locality to clarify the systematics of the hypercarnivorous taxa from the French MN6 reference site. The history of the correct assignment of the type material from Sansan was first summarized by Heizmann (1973) and later extended by Rothwell (2003) in his revision of North American Pseudaelurus. Pseudaelurus is known in Europe from MN3a to MN10 (Ginsburg 1999; NOW), with $P$. cf. lorteti (Gaillard 1899) from the Middle Sinap formation representing the last occurrence. However, if the smallest species, $P$. turnauensis (Hoernes 1882), is assigned to the subgenus Schizailurus (Viret 1951) (see Morlo 1997 for the most recent discussion on this topic), Pseudaelurus was present in Europe from MN4 to MN10.

Pseudaelurus romieviensis Roman and Viret, 1930.

1908 Pseudaelurus quadridentatus, Blainville-Mayet: 24.

*1930 P. quadridentatus, Blainv. mutation romieviensis Roman and Viret: 19-23, pl. II fig. 4-7 (Fig. 9).

1973 Pseudailurus romieviensis, Roman \& ViretHeizmann: 1-95, fig. 15b.

Material: 8050: right mandible with $\mathrm{c}$ inf., alveoli for p3, p3 with broken main cusp, m1 (Fig. 11q-s); 8052: left mandible with c inf., p3, p4 lingual side damaged, m1 (Fig. 10); 8209: right mandible fragment with $\mathrm{m} 1$ (Fig. 11k-m); 16219: left maxillar fragment with Csup., P2-P4; 8129: left maxillar fragment with P4 and alveoli of P3 (Fig. 11n-p); 8062: right cinf.; 8140: left P3 anterior part missing; 8237: left $\mathrm{P} 4$, only anterior part with protocone preserved; 8056: right $\mathrm{P} 4$, protocone broken; 8233: left P3.

Description and comparisons: On both lower jaw fragments the foramina mentalia are under the diasteme and under the posterior root of the p3. 8052 has a very small gap between the lower canine and p3 $(7 \mathrm{~mm})$. No alveolus of a p 2 can be verified due to the poor condition of the mandible, but 8050 presents a tiny trace of an alveolus. 
Fig. 9 Scatter diagram of upper dentition of Hemicyon stehlini from Sandelzhausen, compared [comparative measurements from Ginsburg (1965) and Ginsburg and Morales (1998)]. Each point represents an individual specimen
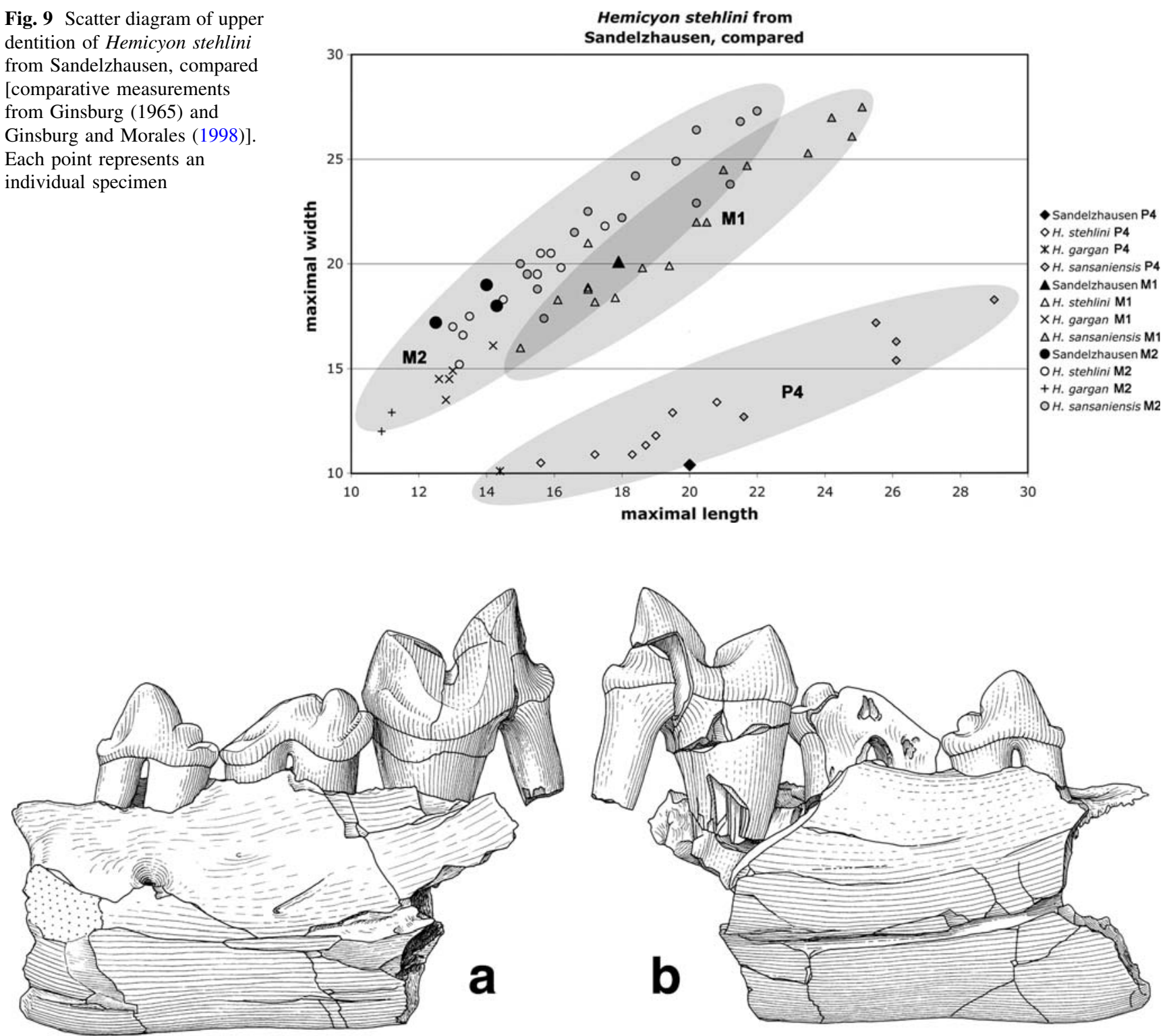

$1 \mathrm{~cm}$

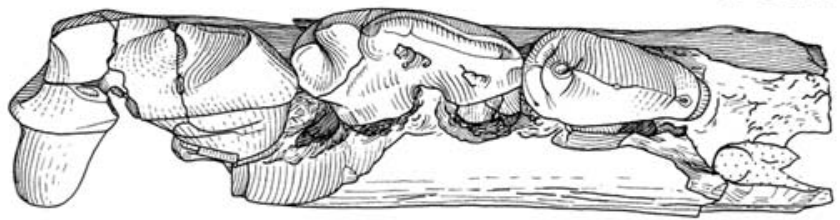

C

Fig. 10 Pseudaelurus romieviensis Roman and Viret, 1930: 8052. a Buccal view, b lingual view, c occlusal view

Therefore it is impossible to know whether a p2 was developed in 8052 or not.

The p3 is only preserved in 8052 and has a small anterior cusplet and posterior cusp as well as a cingulid specially developed at its posterior end. The main cusp of p4 is broken in 8050 but a small anterior cusp and a strong posterior cusp are still visible. The latter is also preserved in 8052 where the lingual part is damaged. Posteriorly, the tooth displays a strong cingulid. The $\mathrm{m} 1$ is well preserved in 8050,8052 , and 8209 . It overlaps the p4 slightly. The protoconid is taller than the paraconid; the metaconid is much reduced and blends into an abridged talonid. The talonid is very small in 8209 and 8052 , but a bit larger in 8052. The P3 has no anterior cusp but a well-defined 

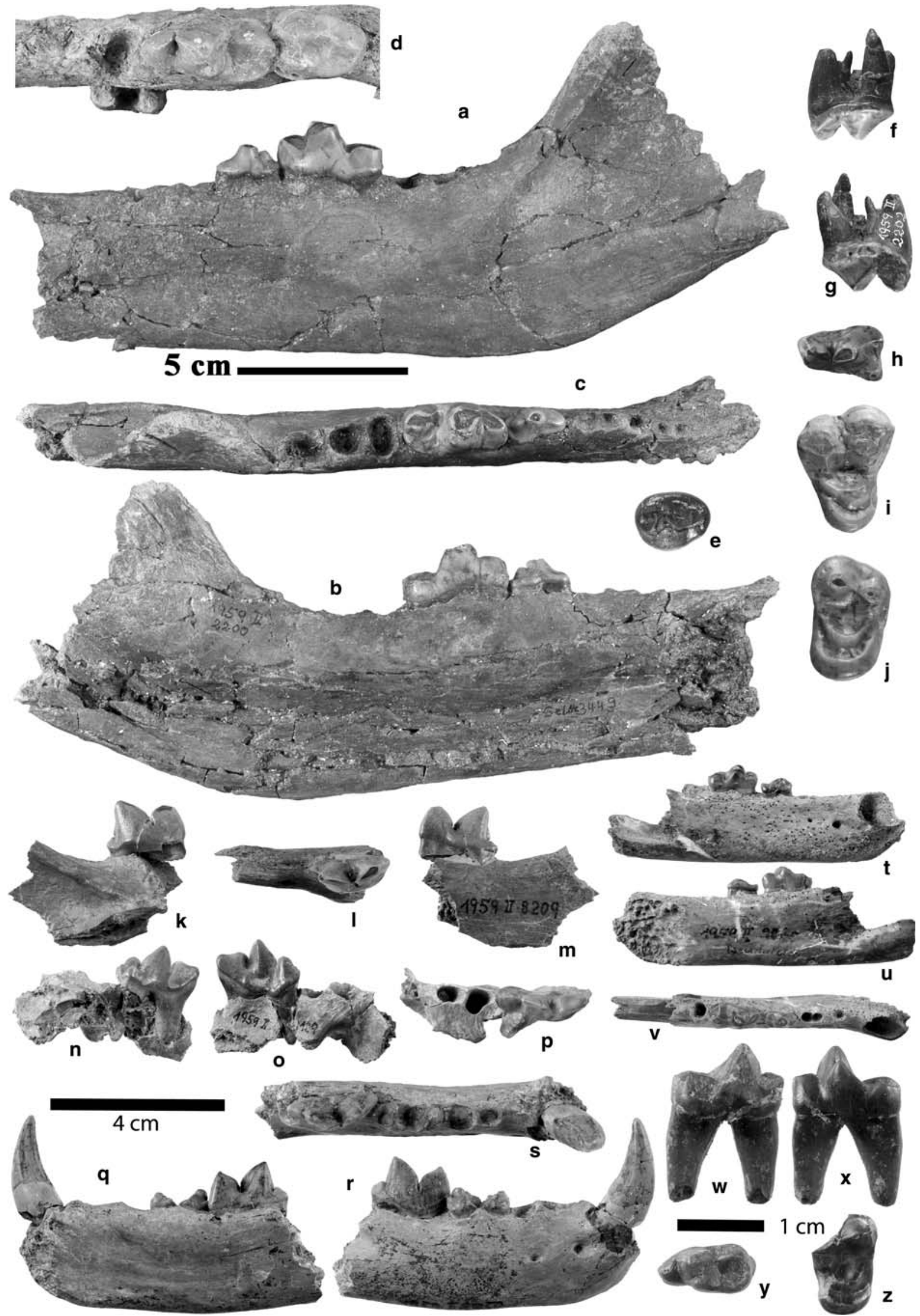
Fig. 11 a-j Amphicyon cf. major (Blainville, 1841); a-c 2200, left mandible with p4-m1; a buccal view, b lingual view, c occlusal view, d 8095 , right mandible with $\mathrm{m} 1-\mathrm{m} 2$, occlusal view, e 8082, left $\mathrm{m} 3$, occlusal view, f-h 2202, right P4, f buccal view, g lingual view, h occlusal view, i 2213, right M1, occlusal view; j 8098, right M2, occlusal view, $\mathbf{k}-\mathbf{s}$ Pseudaelurus romieviensis Roman and Viret 1930, $\mathbf{k}-\mathbf{m}$ 8209, right mandible fragment with $\mathrm{m} 1$, $\mathbf{k}$ buccal view, I occlusal view, m lingual view, $\mathbf{n}-\mathbf{p}$ 8129, left maxillar fragment with P4, $\mathbf{n}$ buccal view, o lingual view, $\mathbf{p}$ occlusal view, q-s 8050, right mandible with p4-m1, q lingual view, $\mathbf{r}$ buccal view, s occlusal view, $\mathbf{t}-\mathbf{Z}$ Pseudarctos b. bavaricus (Schlosser 1899), t-v 8060, right mandible with $\mathrm{p} 4-\mathrm{m} 1, \mathbf{t}$ buccal view, $\mathbf{u}$ lingual view, $\mathbf{v}$ occlusal view, $\mathbf{w}-\mathbf{y} 8081$, right $\mathrm{m} 1$, w buccal view, $\mathbf{x}$ lingual view, $\mathbf{y}$ occlusal view, $\mathbf{z}$ 5295, right $\mathrm{m} 3$, occlusal view

posterior one and a strong posterior cingulum. The upper carnassial carries a strong slightly trenching protocone, which is implanted further forward than the parastyle. The parastyle is larger than the protocone but no preparastyle is developed. The paracone is high and of the same size as the metastyle blade.

The specimen differs from the similarly sized barbourofelid Prosansanosmilus eggeri, known from Sandelzhausen as well (see below), in lacking a preparastyle in P4, no metaconid present in $\mathrm{m} 1$, and lacking a flange.

Discussion: Heizmann (1973) revised the European Pseudaelurus and accepted four species based on an increase in size: $P$. turnauensis, $P$. lorteti, $P$. romieviensis, and $P$. quadridentatus and two different lineages. One is the $P$. romieviensis $-P$. quadridentatus lineage and the other leads from P. turnauensis to P. lorteti. However, Morlo (1997) argued for a close relationship of "P." turnauensis to Felis attica, which would make $P$. turnauensis paraphyletic - the main argument to place it into Schizailurus (de Beaumont). While the African specimens all are summarized as P. turnauensis (Thomas et al. 1982), most of the Asian and North American forms are described as different species (Cao et al. 1990; Wang et al. 1998; Rothwell 2003).

$P$. turnauensis is the smallest and earliest Pseudaelurus species. It may have $\mathrm{p} 2$ and the $\mathrm{m} 1$ metaconid completely reduced.

In $P$. lorteti the mental foramens are placed under the diasteme and under the anterior root of p3. The buccal part of the tooth is somewhat rugose and the p2 is either very reduced or lost. In p3 and p4 the main cusp is lower in comparison with $P$. turnauensis and $P$. romieviensis. Both premolars carry an anterior cusp as well as a posterior one. In $\mathrm{m} 1$, the paraconid is lower than the protoconid, the metaconid is small, and the talonid can be slightly or very reduced. In general it is intermediate in size between $P$. turnauensis and $P$. romieviensis.

Pseudaelurus romieviensis has high premolars with an anterior cusp only in $\mathrm{p} 3$. In $\mathrm{m} 1$, the protoconid is higher than the paraconid, the metaconid already small and placed further back, with the talonid built as a cutting edge. In P4 of $P$. romieviensis, the protocone is the anteriormost part of the tooth and clearly detached. A cingulum can be found in the anterior buccal part, but no cusp is developed.

On $P$. quadridentatus the foramina mentalia are under the diastemes and under the posterior root of p3. The p4 is relatively longer than in all other species of Pseudaelurus (Fig. 12). The $\mathrm{m} 1$ has protoconid and paraconid of almost equal height and metaconid and talonid very reduced. In $\mathrm{P} 4$, the anterior cingulum is stronger while the preparastyle is smaller and the protocone is lower.

In $P$. quadridentatus the $\mathrm{m} 1$ overlaps the $\mathrm{p} 4$ slightly, the protoconid is a bit wider developed than the paraconid, and the metaconid is more reduced than in all the other Pseudaelurus species and almost a part of the talonid.

In $P$. romieviensis, the tooth dimensions are smaller than in P. quadridentatus and the mandible is less robust.
Fig. 12 Scatter diagram of the length of $\mathrm{m} 1$ versus length of $\mathrm{p} 4$ of different Pseudaelurus species. Comparative measurements were taken from Roman and Viret (1930), Heizmann (1973), and Ginsburg and Bulot (1982). Each point represents an individual specimen

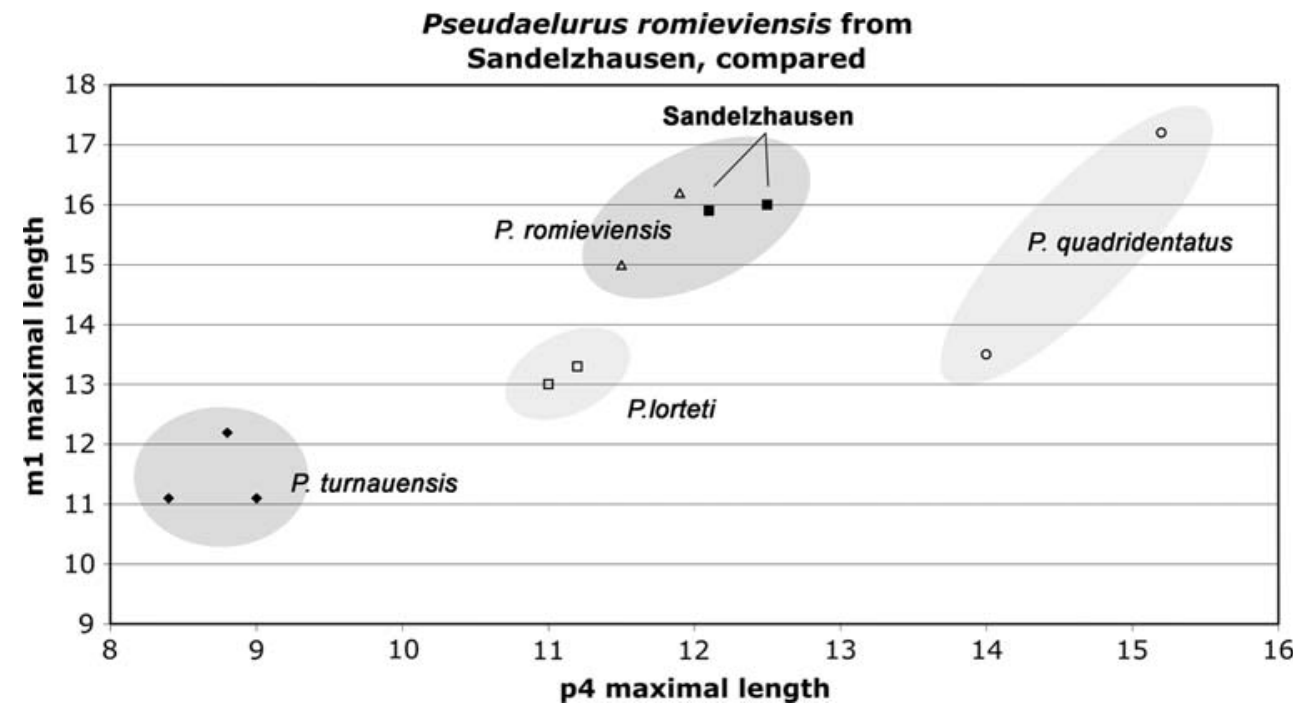


No $\mathrm{p} 2(\mathrm{p} 1)$ is reported so far. The $\mathrm{p} 3$ bears a small and $\mathrm{p} 4$ a distinct posterior cusp. Additionally, both teeth have a cingulid, which is well developed posteriorly, and a main cusp higher than in P. quadridentatus. The protoconid on the $\mathrm{m} 1$ is higher than the paraconid and therefore the angle between the two cusps is narrower than in $P$. quadridentatus. The metaconid is strongly reduced and is part of the talonid, which is not yet as small as in $P$. quadridentatus.

The size of the mandible and teeth as well as the short diasteme put the material from Sandelzhausen into the P. romieviensis group (Fig. 12). The $\mathrm{p} 3$ has a high main cusp and the $\mathrm{p} 4$ has a distinct posterior cusp. Unfortunately, the main cusp of both preserved $\mathrm{p} 4$ is broken (8050, 8052), so nothing can be said about the height of this tooth. The $P$. romieviensis $-P$. quadridentatus line is characterized by an increase of the $\mathrm{p} 4$ in comparison with $\mathrm{m} 1$. The measurements of the length of $\mathrm{p} 4$ compared with the length of the $\mathrm{m} 1$ show strong similarities to $P$. romieviensis (Fig. 12). The protoconid on $\mathrm{m} 1$ is higher than the paraconid. The metaconid is very reduced and probably only visible as a part of the trenching talonid of 8050 .

Distribution: P. romieviensis is known so far from France: Chevilly (MN4), La Romieu (MN4), Baigneauxen-Beauce (MN5), Bézian (MN4), from Spain: Els Casots (MN4), and now from Sandelzhausen (MN5). Heizmann (1973) discussed also one specimen from Häder as a possible $P$. romieviensis, which was added by Ginsburg (1999) to his summary about the European Pseudaelurus quadridentatus. Based on the measurements and morphological details, though, it is reasonable to follow Heizmann in this matter. $P$. romieviensis is only known from Europe so far and only from MN4 to MN5, when it probably gave way to the next evolutionary step, P. quadridentatus (Table 7).

Family Barbourofelidae (Schultz et al. 1970) sensu Morlo et al. 2004.

Genus Prosansanosmilus Heizmann, Ginsburg, \& Bulot, 1980.

Type species: Prosansanosmilus peregrinus Heizmann, Ginsburg, \& Bulot, 1980.

Prosansanosmilus eggeri Morlo, Peigné, and Nagel, 2004.

1996 Pseudailurus sp.-Fahlbusch and Liebreich: 30, fig. $34 \mathrm{~b}$.

*2004 P. eggeri Morlo, Peigné, and Nagel: 45-50, fig. 1-3.

Material: 8051: right mandible with $\mathrm{p} 3-\mathrm{m} 1$ (holotyp); 11.553: left mandible fragment with $\mathrm{p} 4-\mathrm{m} 1 ; 8058$ : right $\mathrm{p} 3$; 8053: fragment of right mandible with distal part of $\mathrm{p} 3$, p4-m1; 8054: fragment of left mandible with broken $\mathrm{p} 4$, $\mathrm{m} 1$; 8057: isolated fragment of left p4. 8058: isolated p4; 9041, fragment of left mandible; 8055: left maxillar fragment with P3-P4.
Table 7 Teeth measurements ( $\mathrm{mm}$ ) from Pseudaelurus romieviensis Roman and Viret, 1930

\begin{tabular}{llllll}
\hline Coll. no. & Element & $\begin{array}{l}\text { Total } \\
\text { length }\end{array}$ & $\begin{array}{l}\text { Total } \\
\text { width }\end{array}$ & $\begin{array}{l}\text { Trigonid } \\
\text { length }\end{array}$ & $\begin{array}{l}\text { Talonid } \\
\text { width }\end{array}$ \\
\hline 8129 md sin & P3 & 11.3 & 4.7 & & \\
8129 md sin & P4 & 18.2 & 9.8 & & \\
8233 dext & P3 & 10.9 & 5.8 & & \\
8056 dext & P4 & 17.5 & 7.4 & & \\
8045 sin & Csup & 12.0 & 8.2 & & \\
8045 sin & P2 & 3.2 & 2.4 & & \\
8045 sin & P3 & 11.1 & 6.8 & & \\
8045 sin & P4 & 16.2 & - & & \\
8052 md sin & cinf & 10.8 & 8.1 & & \\
8052 md sin & p3 & 9.4 & 5.1 & & \\
8052 md sin & p4 & 12.1 & - & & \\
8052 md sin & m1 & 15.9 & - & 13.4 & \\
8209 dext & m1 & 15.3 & - & 13.7 & 2.9 \\
8050 md dext & cinf & 8.3 & 6.4 & & \\
8050 md dext & p3 & 9.8 & 5.1 & & \\
8050 md dext & p4 & 12.5 & 5.4 & & \\
8050 md dext & m1 & 16.0 & - & 13.4 & \\
8062 dext & cinf & 8.0 & 6.4 & & \\
\hline
\end{tabular}

Description and comparisons: The holotype has been known since 1959 but because of its similarity to Pseudaelurus, it was not interpreted correctly. The complete material was described in detail by Morlo et al. (2004). The mandible is laterally compressed but nevertheless the flange is clearly visible. Minor differences such as a preparastyle in $\mathrm{P} 4$, the retrorse teeth, and the persistence of the metaconid enable the barbourofelid to be differentiated from its felid counterpart which is also present in Sandelzhausen.

The phylogenetic analysis places this species close to its larger relative, Prosansanosmilus pereginus. P. eggeri probably came from Africa to Europe in MN5, after $P$. peregrinus which is known in Europe from MN4 to MN5 (Morlo 2006). Both may have originated from the African barbourofelid Afrosmilus (Kretzoi 1929), which itself migrated to Europe in MN4 by its species A. hispanicus (Morales et al. 2001), thereby representing the third

Fig. 13 a-d Hemicyon stehlini Huerzeler, 1944. a 8032, skull badly deformed, occlusal view, b-d 8033, left mandible with p3-m3, b lingual view, c buccal view, d occlusal view, e-r Ischyrictis zibethoides (Blainville, 1842), e-g 8040, left mandible with p2-m1, e buccal view, f lingual view, $\mathbf{g}$ occlusal view, $\mathbf{h}-\mathbf{j}$ 8037, left mandible with p1-m1, h buccal view, i lingual view, $\mathbf{j}$ occlusal view, $\mathbf{k}-\mathbf{m} 40$, right lower jaw fragment with $\mathrm{m} 1, \mathbf{k}$ buccal view, l lingual view, $\mathbf{m}$ occlusal view, n 8044, right M1, occlusal view, o 8044, left M1; occlusal view, p-r 8044, left P4, p lingual view, q buccal view, $\mathbf{r}$ occlusal view 


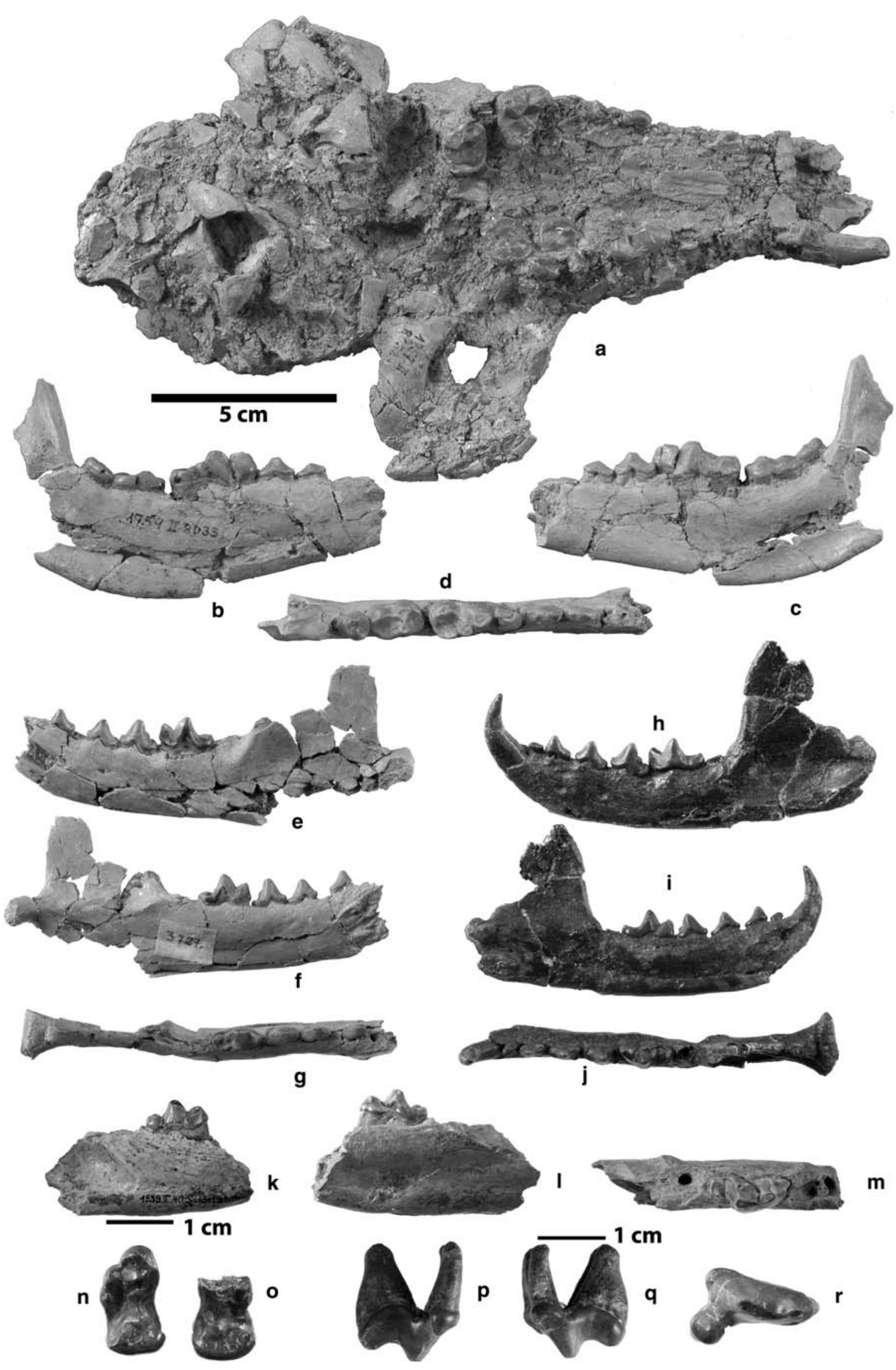


barbourofelid immigration into the early Middle Miocene of Europe (Morlo 2006). The question of whether Sansanosmilus descended from P. eggeri or represents another immigration of Barbourofelidae in MN6 cannot be answered yet.

\section{Conclusion}

The carnivoran species represented in the Sandelzhausen community range in the biochronology of Europe from MN4 to MN9. P. eggeri is only known from MN5 from Sandelzhausen so far. The similarly sized $P$. romieviensis was known only from MN4; therefore the Sandelzhausen specimen is the first reported occurrence from MN5. Hemicyon stehlini also is a species with a restricted stratigraphic range, being known from MN4 to MN5 only. The Sandelzhausen specimens of $P$. bavaricus are morphologically similar to the basal form of this species, known from MN5 to MN8. Amphicyon major, Ischyrictis zibethoides, P. pusillus, and Martes munki have a wider stratigraphic range and therefore do not help to pinpoint the stratigraphic age of the Sandelzhausen locality. Some faunal elements are only known from Europe, such as Ischyrictis zibethoides, P. romieviensis, and Prosansanosmilus eggeri, but the latter also marks an immigration event from Africa in MN5 (Morlo et al. 2004). In general, with the exception of $A$. cf. major, all other carnivorans from Sandelzhausen are quite small. Hyenids such as Plioviverrops or Protictitherium are missing, as is the large creodont Hyainailouros. These elements are usually known from more open landscapes. The composition of the Sandelzhausen carnivoran fauna indicates a more humid climate and a dense forest (Moser et al. 2009). Noticeable is the low diversity of musteloids, which is probably a result of the taphonomical processes that took place in Sandelzhausen. The material was usually very badly crushed during transportation in water and small specimens were likely to have been destroyed. Only by excellent preparation was it possible to retrieve the available information (see Fig. 13a). Nevertheless, the material was probably not transported very far, since elements from single individuals were found in close proximity. Skeletal remains from Amphicyon, Hemicyon, and Pseudaelurus seem to come from very few individuals rather than single elements from many different ones.

Acknowledgments We would like to thank Volker Fahlbusch for entrusting us with the material as well as Gertrud Rössner and Ursula Göhlich (all from Munich) for their patience with the ms and for their help with inventory numbers. Norbert Frotzler made the detailed black and white drawing and Rudolf Gold took the photos (both Vienna). We are grateful for the constructive remarks of our reviewers Elmar Heizmann (Stuttgart) and Lars Werdelin
(Stockholm), which helped to improve this paper. David Ferguson (Vienna) was kind enough to correct the English. The Deutsche Forschungsgemeinschaft is acknowledged for providing funds for C.S. to attend the Sandelzhausen Symposium 2005 in Mainburg (DFG GZ-4850/88/05).

\section{References}

Astibia, H., J. Morales, and L. Ginsburg. 2000. Hemicyon mayorali nov. sp., Ursidae du Miocène moyen de Tarazona de Aragon (basin de l'Ebre, Aragon, Espagne). Annales de Paléontologie 86(1):69-79.

Blainville, H. 1842. Ostéographie ou déscription iconographique comparée du squelette et du système dentaire des cinq classes d'animaux vertebras récents et fossils pour servir de base à la zoologie et à la géologie. Mammiferes Carnassiers: Des Mustelas (Genre Mustela L.) 10:1-83.

Cao, Z., H. Du, Q. Zhao, and J. Cheeng. 1990. Discovery of the Middle Miocene fossil mammals in Guanghe District, Gansu and their stratigraphic significance. Geoscience 4:16-32.

Colbert, E.H. 1939. Carnivora of the Tung Gur Formation of Mongolia. Bulletin of the American Museum of Natural History 76:47-81.

Crusafont, M. 1972. Les Ischyrictis de la transition VindobonienVallésien. Palaeovertebrata 5:253-260.

Daxner-Höck, G. 2003. Mammals from the Karpatian of the Central Paratethys. In The Karpathian-a Lower Miocene Stage of the Central Paratethys, ed. R. Brozobohaty, I. Cicha, M. Kovac, and F. Rögl. Brno: Masaryk University.

Dehm, R. 1950. Die Raubtiere aus dem Mittel-Miocän (Burdigalium) von Wintershof-West bei Eichstätt in Bayern. Abhandlungen der Bayrischen Akademie der Wissenschaften, Mathematisch-naturwissenschaftliche Klasse, Neue Folge 58:1-141.

Fahlbusch, V. 1974a. Aus Bayerns Tierwelt vor 15 Millionen Jahren. Ausgrabungen fossiler Säugetiere im Alpenlvorland. Aufschluss 25:458-465.

Fahlbusch, V. 1974b. Aus Bayerns Tierwelt vor 15 Millionen Jahren. Ausgrabungen fossiler Säugetiere im Alpenvorland. Der Aufschluss 25:458-464.

Fahlbusch, V. 2003. Die miozäne Fossil-Lagerstätte Sandelzhausen. Die Ausgrabungen 1994-2001. Zitteliana A 43:109-121.

Fahlbusch, V., and H. Gall. 1970. Die obermiozäne Fossil-Lagerstätte Sandelzhausen. 1. Entdeckung, Geologie, Faunenübersicht und Grabungsbericht für 1976. Mitteilungen der Bayerischen Staatssammlung für Paläontologie und historische Geologie 10:365396.

Fahlbusch, V., and R. Liebreich. 1996. Hasenhirsch und Hundebär, 40. München: Pfeil.

Fahlbusch, V., and R. Liebreich. 1999. Die Fossilfunstelle Sandelzhausen. Grabung 1998. Jahresbericht 1998 und Mitteilungen. Freunde der Bayerischen Staatsammlung für Paläontologie und historische Geologie München e. V 27:43-51.

Fahlbusch, V., H. Gall, and N. Schmidt-Kittler. 1972. Die obermiozäne Fossil-Lagerstätte Sandelzhausen. 2. Sedimente und Fossilinhallt, Probleme der Genese und Ökologie. Neues Jahrbuch für Geologie und Paläontologie. Monatshefte 1972:331343.

Fahlbusch, V., H. Gall, and N. Schmidt-Kittler. 1974. Die obermiozäne Fossil-Lagerstätte Sandelzhausen. 10. Die Grabungen 1970-73, Beiträge zur Sedimentologie und Fauna. Mitteilungen der Bayerischen Staatssammlung für Paläontologie und historische Geologie 14:103-128.

Fejfar, O. Z. Dvorak, and E. Kadlecova. 2003. New record of Early Miocene (MN3a) mammals in open brown coal pit Merkur, 
North Bohemia, Czech Republic. In Distribution and Migration of Tertiary Mammals in Eurasia, papers in honour of $H$, eds. Reumer, J., and W. Wessels, 10, 163-182. de Bruijn: Deinsea.

Filhol, H.M. 1891. Ètudes sur les mammifères fossils de Sansan. Annales des Science Géologiques XXI:319.

Fraas, O. 1885. Beiträge zur Fauna von Steinheim. Jahreshefte des Vereins für vaterländische Naturkunde in Württemberg 41:313326.

Frick, C. 1926. The Hemicyoninae and an American Tertiary Bear. Bulletin of the American Museum of Natural History 56:1-120.

Gervais, P. 1848-1852. Zoologie et Paléontologie françaises (animaux vertébrès) ou nouvelle recherches sur les animaux vivants et fossiles de la France. 1 reédition, 271. Paris.

Ginsburg, L. 1955. De la subdivision du genre Hemicyon Lartet (Carnassier) du Miocène. Bulletin de la Société Géologique de France 6(5):85-99.

Ginsburg, L. 1961. La faune des carnivores miocènes de Sansan (Gers). Mémoires du Muséum National d'Histoire Naturelle, Séries C IX:1-190.

Ginsburg, L. 1992. Les generes Pseudarctos et Ictiocyon, Amphicyonidae (Carnivora, Mammalia) du Miocène européen. Bulletin du Muséum National d'Histoire Naturelle (4C) 14(3-4):301317.

Ginsburg, L. 1999. Order Carnivora. In Land Mammals of Europe, eds. Rössner, G.E., and K. Heissig., 109-148. München: Pfeil.

Ginsburg, L., and C. Bulot. 1982. Les carnivores du miocène de Bézian prés de la Romieu (Gers, France). Proceedings of the koninklyke Nederlandse Akademie van Wetenschappen. B 85(1):53-76.

Ginsburg, L., and J. Morales. 1992. Contribution à la connaissance des Mustélidés (Carnivora, Mammalia) du Miocène d'Europe Trochictis et Ischyrictis, genres affines et genres nouveaux. Comptes Rendus de l'Académie des Sciences Paris 315(II):111-116.

Ginsburg, L., and J. Morales. 1998a. Zaragocyon daamsi n. gen. sp. nov., Ursidae primitif du Miocène inférieur d'Espagne. Comptes Rendus de l'Académie des Sciences Paris 321(IIIa):811-815.

Ginsburg, L., and J. Morales. 1998b. Les Hemicyoninae (Ursidae, Carnivora, Mammalia) et les formes apparentées de Miocene inférieur et moyen d'Europe occidentale. Annales de Paléontologie 84(1):71-123.

Heizmann, E.P.J. 1973. Die tertiären Wirbeltiere des Steinheimer Beckens. Palaeontographica Supplement 8(5B):1-95.

Heizmann, E.P.J., L. Ginsburg, and C. Bulot. 1980. Prosansanosmilus peregrinus, ein neuer machairodontider Felidae aus dem Miozän Deutschlands und Frankreichs. Stuttgarter Beiträge zur Naturkunde B 58:1-27.

Helbing, H. 1930. Zur Kenntnis der miocänen „Mustela” zibethoides Blainville. Eclogae geologicae Helvetiae 23(2):637-644.

Helbing, H. 1936. Die Carnivoren des Steinheimer Beckens. A: Mustelidae. Palaeontographica. Supplement 8(VA):1-95.

Huerzeler, J. 1944. Zur Revision der europäischen Hemicyoniden. Verhandlung der Naturforschenden Gesellschaft in Basel 55: 131-157.

Hunt, R.M. 1998. Ursidae. Evolution of tertiary mammals of North America. Volume 1: terrestrial carnivores, ungulates and ungulatelike mammals, 174-195. London: Cambridge University Press.

Jourdan, C. 1861. Description de restes fossiles de deux grands Mammifères constituant deux genres, l'un le genre Rhizoprion, de l'ordre des Cétacés et du groupe des Delphinoides, l'autre le genre Dinocyon, de l'ordre des Carnassiers et de la famille des Canidés. Comptes Rendus à l'Académie des Sciences 53:959-963.

Kuss, S.E. 1965. Revision der europäischen Amphicyoninae (Canidae, Carnivora, Mammalia) ausschließlich der voroberstampischen Formen. Sitzungsberichte der Heidelberger Akademie der Wissenschaften, mathematisch-naturwissenschaftliche Klasse 1:168.
Lartet, E. 1851. Notice sur la colline des Sansan. Suivie d'une récapitulation de diverses espèces d'animaux vertébrés fossiles trouvés soit à Sansan, soit dans d'autres gisements du terrain tertiaire miocène dans le bassin sous-pyrénéen, 45. Auches: J.-A. Portes.

Mayet, L. 1908. Études de Mammifères miocènes des sables de l'Orléanais et des faluns de la Touraine. Annales de l'Université de Lyon, Nouvelle Série 24:336.

Morales, J., M. Pickford, D. Soria, and S. Fraile. 1998. New carnivores from the basal Middle Miocene of Arrisdrift, Namibia. Eclogae Geologicae Helvetiae 91:27-40.

Morlo, M. 1997. Die Raubtiere (Mammalia, Carnivora) von DornDürkheim. 1. (Rheinhessen) 1 Mustelida, Hyaenidae, Percrocutidae, Felidae. Courier Forschungsinstitut Senckenberg 197:1147.

Morlo, M. 2006. New remains of Barbourofelidae (Mammalia, Carnivora) from the Miocene of Southern Germany: implications for the history of barbourofelid migrations. Beträge zur Paläontologie 30:339-346.

Morlo, M., St. Peigné, and D. Nagel. 2004. A new species of Prosansanosmilus: implication for the systematic relationship of the family Barbourofelidae new rank (Carnivora, Mammalia). Zoological Journal of the Linnean Society 140:43-61.

Moser, M., G.E. Rössner, U.B. Göhlich, M. Böhme, and V. Fahlbusch. 2009 this volume. The fossil lagerstätte Sandelzhausen (Miocene; southern Germany): history of investigation, geology, fauna and age. In Fossil lagerstätte Sandelzhausen (Miocene, southern Germany): Contributions to the fauna. Paläontologische Zeitschrift, eds. Rössner, G.E., and U.B., Göhlich, 83 (1). 000-000.

Nagel, D. 2003. Carnivora from the middle Miocene Hominoid locality of Çandir (Turkey). Courier Forschungsinstitut Senckenberg 240:113-131.

Peigné, S., and E.P.J. Heizmann. 2003. The Amphicyonidae (Mammalia: Carnivora) from Ulm-Westtangente (MN2, Early Miocene), Baden-Württemberg, Germany, Systematics and ecomorphology. Stuttgarter Beiträge zur Naturkunde B 343:133.

Qiu, Z. 2003. Dispersal of Neogene Carnivorans between Asia and North America. Chapter 2. Bulletin American Museum of Natural History 279:18-31.

Roger, O. 1900. Wirbeltierreste aus dem Dinotheriensande der schwäbisch-bayerischen Hochebene. 3. Teil. Berichte des naturwissenschaftlichen Vereins für Schwaben und Neuburg in Augsburg 34:54-70.

Roman, F., and J. Viret. 1930. Le Miocène continental de l'Armagnac et le gisement burdigalien de La Romieu (Gers). Livre Jubilaire (Société Géologique de France): 577-604.

Roth, C.H. 1988. Leptoplesictis Major 1903 (Mammalia, Carnivora, Viverridae) aus dem Orleanium und Asteracium/Miozän von Frankreich und Deutschland. Paläontologische Zeitschrift 62(3/ 4):333-343.

Roth, C.H. 1989. Die Raubtierfauna (Carnivora, Mammalia) der untermiozänen Spaltenfüllung von Erkertshofen 2 bei Eichstätt/ Bayern. Mitteilungen der Bayerischen Staatssammlung für Paläontologie und historische Geologie 29:163-205.

Rothwell, T. 2003. Phylogenetic Systematics of Northern American Pseudailurus (Carnivora: Felidae). American Museum Novitates 3403:64.

Schlosser, M. 1899. Über die Bären und bärenähnlichen Formen des europäischen Tertiärs. Palaeontographica 45:95-147.

Schmidt-Kittler, N. 1976. Raubtiere aus dem Jungtertiär Kleinasiens. Palaeontographica Abt. A 155(1-4):1-131.

Schmidt-Kittler, N. 1987. The Carnivora (Fissipedia) from the Lower Miocene of East Africa. Palaeontographica, A 197:85-126.

Stehlin, H.G., and H. Helbing. 1925. Catalogue des ossements de mammifères Tertiaires de la Collection Bourgeois à l'Ecole de 
Pont-Levoy (Loir-et-Cher). Bulletin de la Société naturelles et Anthropologie de Loir-et-Cher 18:77-277.

Thenius, E. 1989. Zähne und Gebiß der Säugetiere. In Handbuch der Zoologie, ed. J. Niethammer, H. Schliemann, and D. Starck, 513. VIII Mammalia: Walter de Gruyer.

Thomas, H., S. Sen, M. Khan, B. Battail, and G. Ligabue. 1982. The lower Miocene fauna of Al-Sarrar (Eastern province, Saudi Arabia). The Journal of Saudi Arabian Archaeology 5:109-135.

Toula, F. 1884. Über Amphicyon, Hyaemoschus und Rhinoceros (Aceratherium) von Göriach be Turnau in der Steiermark. Sitzungsberichte der Kaiserlichen Akademie der Wissenschaften. Mathematisch-Naturwissenschaftliche Klasse 90(5):405428.

Viranta, S. 1996. European Miocene Amphicyonidae-taxonomy, systematics and ecology. Acta Zoologica Fennica 204:1-61.
Viret, J. 1933. Contribution à l'Ètude des Carnassiers Miocènes de la Grive-Saint-Alban (Isère). Travaux du Laboratoire de Géologie de la Faculté des Sciences de Lyon 21(18):1-31.

Viret, M.J. 1951. Catalogue critique de la faune des Mammifères Miocènes da la grive Saint-Alban (Isère). Nouvelles archives $d u$ muséum d'histoire naturelle de Lyon 3:1-104.

Wang, X., J. Ye, J. Meng, W. Wu, L. Liu, and S. Bi. 1998. Carnivora from middle Miocene of northern Junggar Basin, Xinjiang Autonomous Region, China. Vertebrata Palasiatica 36:218-243.

Werdelin, L. 1996. Carnivores, exclusive of Hyaenidae, from the Later Miocene of Europe and Western Asia. In The Evolution of Western Eurasian Neogene Mammal Faunas, ed. R. Bernor, V. Fahlbusch, and H.-W. Mittmann, 271-289. New York: Columbia University. 